DOE/ID-11441 (2013)

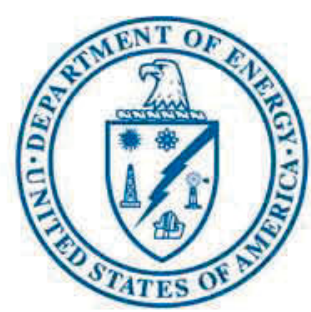

U.S. Department of Energy

Idaho Operations Office

\title{
National Emission Standards for Hazardous Air Pollutants-Calendar Year 2012 INL Report for Radionuclides
}

June 2013

TIIdaho National Laboratory 

DOE/ID-11441 (2013)

\section{National Emission Standards for Hazardous Air Pollutants-Calendar Year 2012 INL Report for Radionuclides}

June 2013 



\begin{abstract}
This report documents the calendar year 2012 radionuclide air emissions and resulting effective dose equivalent to the maximally exposed individual member of the public from operations at the Department of Energy's Idaho National Laboratory Site. This report was prepared in accordance with the Code of Federal Regulations, Title 40, "Protection of the Environment," Part 61, "National Emission Standards for Hazardous Air Pollutants," Subpart H, "National Emission Standards for Emissions of Radionuclides Other than Radon from Department of Energy Facilities." The effective dose equivalent to the maximally exposed individual member of the public was $3.57 \mathrm{E}-02$ mrem per year, 0.36 percent of the 10 mrem per year standard.
\end{abstract}




\section{CONTENTS}

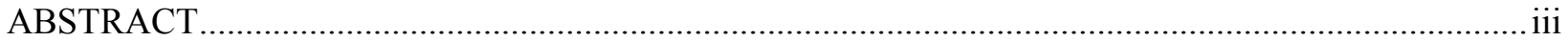

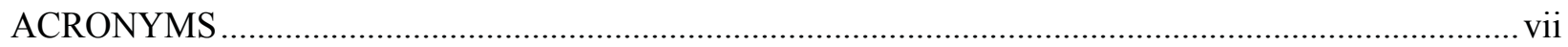

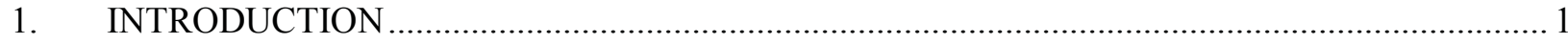

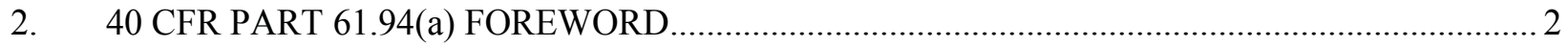

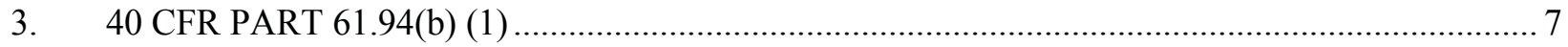

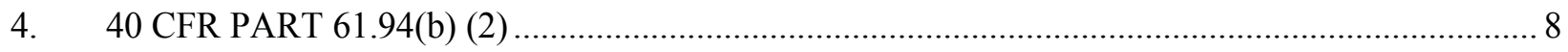

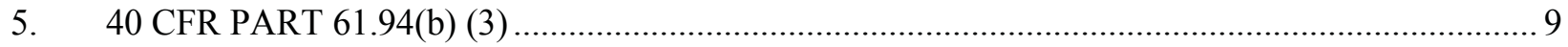

5.1 Advanced Mixed Waste Treatment Project …................................................................... 9

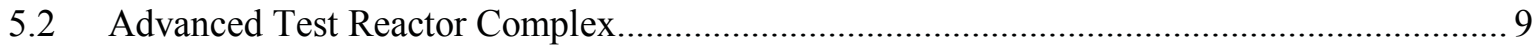

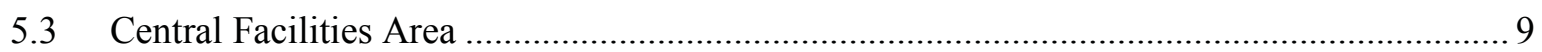

5.4 Idaho Nuclear Technology and Engineering Center ...................................................... 10

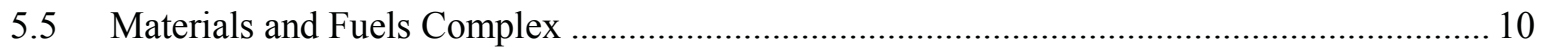

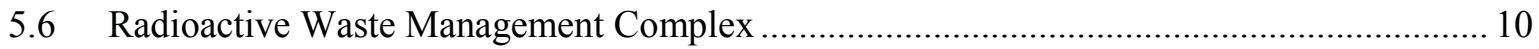

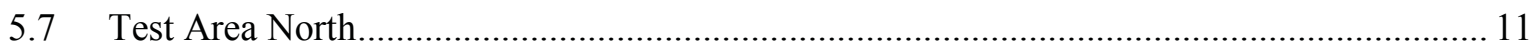

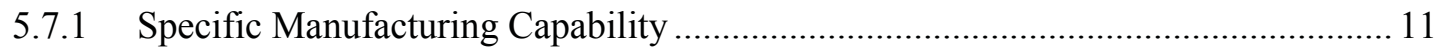

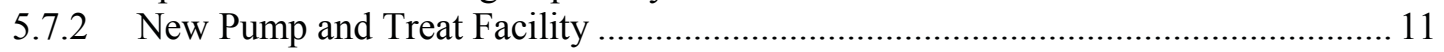

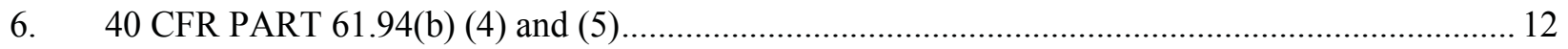

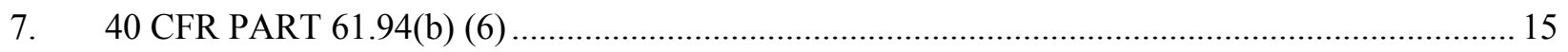

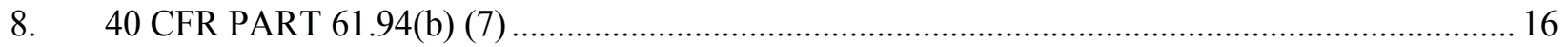

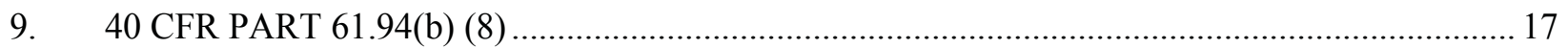

Appendix A INL Research and Education Complex ..................................................................... 1

Appendix B Naval Reactors Facility National Emission Standards for Hazardous Air

Pollutants—Radionuclides Annual Report for 2012 ................................................................. 1

\section{FIGURES}

Figure 1. INL Site, including major facility areas and off-site MEI located at Frenchman's Cabin. ......... 7 


\section{TABLES}

Table 1. Radionuclide emissions, in curies (Ci), from INL Site point sources during CY 2012............... 2

Table 2. Sources used to calculate the EDE to the MEI.

Table 3. INL facility dose (mrem) contributions and total INL Site dose (mrem) to the MEI located at Frenchman's Cabin for CY 2012 radionuclide air emissions.

Table 4. Radionuclides in use and potentially emitted to the atmosphere from INL Site facilities in CY 2012. . .8

Table 5. Stacks, vents, or other points of radioactive materials release to the atmosphere at AMWTP..... 12

Table 6. Stacks, vents, or other points of radioactive materials release to the atmosphere at ATR Complex.

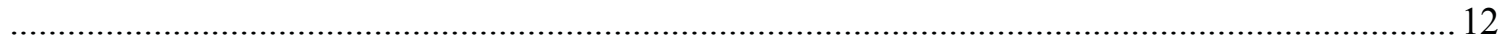

Table 7. Stacks, vents, or other points of radioactive materials release to the atmosphere at CFA........... 12

Table 8. Stacks, vents, or other points of radioactive materials release to the atmosphere at INTEC........ 13

Table 9. Stacks, vents, or other points of radioactive materials released to the atmosphere at MFC........ 13

Table 10. Stacks, vents, or other points of radioactive materials release to the atmosphere at RWMC..... 14

Table 11. Stacks, vents, or other points of radioactive materials release to the atmosphere at TAN-SMC.

Table 12. Stacks, vents, or other points of radioactive materials release to the atmosphere at TAN-TSF. 14

Table 13. Distances from INL facility points of release to the nearest off-Site receptor location and to

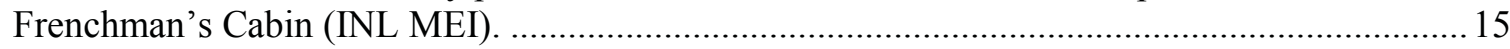

Table 14. Description of data tables in NESHAP CAP88 database ..................................................... 16

Table 15. INL Site meteorological files and wind measurements heights........................................... 16 


\section{ACRONYMS}

\begin{tabular}{|c|c|}
\hline AMWTF & Advanced Mixed Waste Treatment Facility \\
\hline AMWTP & Advanced Mixed Waste Treatment Project \\
\hline ARP & Accelerated Retrieval Project \\
\hline ATR & Advanced Test Reactor \\
\hline ATR Complex & Advanced Test Reactor Complex \\
\hline BEA & Battelle Energy Alliance, LLC \\
\hline CAP & Clean Air Act Assessment Package \\
\hline CEM & Continuous Emission Monitoring \\
\hline CERCLA & Comprehensive Environmental Response, Compensation, and Liability Act \\
\hline CFA & Central Facilities Area \\
\hline CFR & Code of Federal Regulations \\
\hline $\mathrm{Ci}$ & curies \\
\hline $\mathrm{CPP}$ & Chemical Processing Plant \\
\hline CWI & CH2M-WG Idaho, LLC \\
\hline CY & calendar year \\
\hline D\&D & deactivation and decommissioning \\
\hline DOE & Department of Energy \\
\hline DOE-ID & Department of Energy Idaho Operations Office \\
\hline EDE & effective dose equivalent \\
\hline EML & Electron Microscopy Laboratory \\
\hline EPA & Environmental Protection Agency \\
\hline FAST & Fluorinel and Storage Facility \\
\hline FCF & Fuel Conditioning Facility \\
\hline FMF & Fuel Manufacturing Facility \\
\hline HEPA & high-efficiency particulate air \\
\hline HFEF & Hot Fuel Examination Facility \\
\hline ICE & Inner Contamination Enclosure \\
\hline ICP & Idaho Cleanup Project \\
\hline INL & Idaho National Laboratory \\
\hline INTEC & Idaho Nuclear Technology and Engineering Center \\
\hline IRC & INL Research Center \\
\hline LLMW & low-level mixed waste \\
\hline $\mathrm{L} \& \mathrm{O}$ & Laboratory and Office Building \\
\hline MEI & maximally exposed individual \\
\hline MFC & $\begin{array}{l}\text { Materials and Fuels Complex } \\
\text { millirem }\end{array}$ \\
\hline MTR & Material Test Reactor \\
\hline NESHAP & National Emission Standards for Hazardous Air Pollutants \\
\hline NPTF & New Pump and Treat Facility \\
\hline NRF & Naval Reactors Facility \\
\hline NWCF & New Waste Calcining Facility \\
\hline
\end{tabular}


OCVZ Organic Contamination in the Vadose Zone

OU

operable unit

QC quality control

RCE Retrieval Contamination Enclosure

RESL Radiological and Environmental Sciences Laboratory

RCRA Resource Conservation and Recovery Act

RDD radiological dispersion device

RWMC Radioactive Waste Management Complex

SDA Subsurface Disposal Area

SMC Specific Manufacturing Capability

TAN Test Area North

TMI Three Mile Island

TRA Test Reactor Area

TSF

Technical Support Facility

WAG Waste Area Group

WMF Waste Management Facility 


\section{National Emission Standards for Hazardous Air Pollutants-Calendar Year 2012 INL Report for Radionuclides}

\section{INTRODUCTION}

This report documents radionuclide air emissions for calendar year (CY) 2012 and the resulting effective dose equivalent (EDE) to the maximally exposed individual (MEI) member of the public from operations at the U.S. Department of Energy's (DOE's) Idaho National Laboratory (INL) Site.

The title of each section in this report corresponds to reporting requirements found in 40 Code of Federal Regulations (CFR) Part 61.94. A description of the applicable reporting requirements is cited under the titles in italicized text followed by the compliance report for INL Site facilities.

Appendix A contains information specific to INL Research and Education Complex (REC) which includes the INL Research Center (IRC) and the Radiological and Environmental Sciences Laboratory (RESL) emissions located in Idaho Falls, Idaho. Radionuclide emissions from the REC are not included in INL Site EDE calculation since the facilities are not contiguous. Compliance to the 10 millirem (mrem) per year dose standard is demonstrated by documenting REC radionuclide air emissions and the resulting EDE to its MEI member of the public from operations at the IRC and RESL.

Appendix B of this report contains information specific to the Naval Reactors Facility (NRF) located within INL Site boundary. The EDE for NRF radionuclide emissions is included in INL Site EDE to demonstrate overall compliance to the 10-mrem/year dose standard set by 40 CFR Part 61, Subpart H, "National Emission Standards for Emissions of Radionuclides other than Radon from Department of Energy Facilities."

For CY 2012, modeling was performed using Clean Air Act Assessment Package (CAP)88-PC, Version 3 (Release 2-9-2013). 


\section{40 CFR PART 61.94(a) FOREWORD}

"Compliance with this standard shall be determined by calculating the highest effective dose equivalent to any member of the public at any offsite point where there is a residence, school, business or office. The owners or operators of each facility shall submit an annual report to both Environmental Protection Agency (EPA) headquarters and the appropriate regional office by June 30, which includes the results of the monitoring as recorded in DOE's Effluent Information System and the dose calculations required by $\$ 61.93($ a) for the previous calendar year."

This report documents INL Site radionuclide air emissions and the resulting EDE to the MEI for CY 2012. It was prepared in accordance with the 40 CFR 61, Subpart H. As required, this report is submitted to both the EPA Headquarters and the appropriate regional office (EPA Region 10) no later than June 30, 2013.

Table 1 reports the annual radionuclide emissions for INL Site sources that require continuous monitoring for compliance during CY 2012. Table 2 lists the sources used to calculate the EDE to the MEI.

Table 1. Radionuclide emissions, in curies (Ci), from INL Site point sources during CY 2012.

\begin{tabular}{|c|c|c|c|c|c|c|c|c|c|c|c|}
\hline \multicolumn{2}{|c|}{ Radionuclide } & $\begin{array}{c}\mathrm{MFC}^{\mathrm{c}}- \\
785-018 \\
\end{array}$ & $\begin{array}{c}\text { MFC- } \\
764-001\end{array}$ & $\begin{array}{l}\text { MFC- } \\
704-08 \\
\end{array}$ & $\begin{array}{l}\text { ARPs } \\
\text { I-VII7 }^{\mathrm{a}} \\
\end{array}$ & $\begin{array}{c}\mathrm{CPP}^{\mathrm{c}}-708- \\
001\end{array}$ & $\begin{array}{c}\text { CPP-659- } \\
033^{\mathrm{b}}\end{array}$ & $\begin{array}{c}\text { CPP-767- } \\
001^{\mathrm{b}} \\
\end{array}$ & $\begin{array}{l}\mathrm{WMF}^{\mathrm{c}}- \\
636-002^{\mathrm{b}}\end{array}$ & $\begin{array}{c}\text { WMF-67 } \\
002^{\mathrm{b}}\end{array}$ & $\begin{array}{c}\text { WMF-676- } \\
003^{\mathrm{b}} \\
\end{array}$ \\
\hline \multicolumn{2}{|l|}{ Am-241 } & - & - & - & 4.33E-04 & - & - & - & - & - & - \\
\hline \multicolumn{2}{|l|}{ Ar-41 } & - & - & - & - & - & - & - & - & - & - \\
\hline \multicolumn{2}{|l|}{ Co-60 } & - & - & - & - & - & - & - & - & - & - \\
\hline \multicolumn{2}{|l|}{ Cs-137 } & - & - & - & - & $3.22 \mathrm{E}-05$ & - & - & - & - & - \\
\hline \multicolumn{2}{|l|}{$\mathrm{H}-3$} & - & - & - & - & - & - & - & - & - & - \\
\hline \multicolumn{2}{|l|}{ I-129 } & - & - & - & - & $1.35 \mathrm{E}-05$ & - & - & - & - & - \\
\hline \multicolumn{2}{|l|}{$\mathrm{Kr}-85$} & - & - & - & - & - & - & - & - & - & - \\
\hline \multicolumn{2}{|l|}{$\mathrm{Pu}-238$} & - & - & - & - & $2.07 \mathrm{E}-07$ & - & - & - & - & - \\
\hline \multicolumn{2}{|l|}{ Pu-239 } & $5.98 \mathrm{E}-08$ & $1.62 \mathrm{E}-08$ & $1.49 \mathrm{E}-08$ & $1.27 \mathrm{E}-04$ & $1.63 \mathrm{E}-08$ & - & - & - & - & - \\
\hline \multicolumn{2}{|l|}{$\mathrm{Pu}-240$} & - & - & - & $1.54 \mathrm{E}-05$ & - & - & - & - & - & - \\
\hline \multicolumn{2}{|l|}{ Sb-125 } & - & - & - & - & - & - & - & - & - & - \\
\hline \multirow[t]{4}{*}{ Sr-90 } & & 2.49E-07 & $1.7 \mathrm{E}-07$ & $6.00 \mathrm{E}-08$ & - & $5.44 \mathrm{E}-06$ & - & - & - & - & - \\
\hline & a. & \multicolumn{10}{|c|}{$\begin{array}{l}\text { Radionuclide emissions from the standby and ongoing excavation operations at Accelerated Retrieval Enclosure } \\
\text { (ARP) enclosures and Waste Management Facility WMF-1617 are calculated and presented here to demonstrate } \\
\text { INL site-wide compliance using the CAP88-PC model (see discussion of ARP in section 5.6). Radionuclide } \\
\text { emissions include operations and decontamination and decommissioning (D\&D) of the ARP I and VII } \\
\text { enclosures during CY } 2012 \text {. }\end{array}$} \\
\hline & b. & \multicolumn{10}{|c|}{ No measurable emissions in 2012.} \\
\hline & c. & \multicolumn{10}{|c|}{ Materials and Fuels Complex (MFC } \\
\hline
\end{tabular}


Table 2. Sources used to calculate the EDE to the MEI.

\begin{tabular}{|c|c|}
\hline Facility & Source \\
\hline \multirow{6}{*}{$\begin{array}{l}\text { Advanced Mixed } \\
\text { Waste Treatment } \\
\text { Project (AMWTP): }\end{array}$} & Waste Management Facility (WMF)-615-001, Drum Vent Facility \\
\hline & WMF-628-002, Drum Treatment Facility \\
\hline & WMF-634-001, Characterization Facility \\
\hline & WMF-636-001, Transuranic Storage Area-Retrieval Enclosure \\
\hline & WMF-TR-14-001 Analytical Laboratory \\
\hline & WMF-TR-14-002 Analytical Laboratory \\
\hline \multirow[t]{8}{*}{$\begin{array}{l}\text { Advanced Test Reactor } \\
\text { (ATR) Complex: }\end{array}$} & $\begin{array}{l}\text { Test Reactor Area (TRA)-670-074, Advanced Test Reactor (ATR) Chemistry } \\
\text { Laboratory fume hoods exhaust }\end{array}$ \\
\hline & TRA-670-086, laboratory \\
\hline & TRA-670, ATR canal \\
\hline & TRA-678-001, Radiation Measurements Laboratory fume hoods vent \\
\hline & TRA-710-001, Materials Test Reactor (MTR) stack \\
\hline & TRA-715-001, Warm Waste Evaporation Pond \\
\hline & TRA-770-001, ATR main stack \\
\hline & TRA-1627-001, Radioanalytical Chemistry Laboratory \\
\hline \multirow{2}{*}{$\begin{array}{l}\text { Central Facilities Area } \\
\text { (CFA): }\end{array}$} & CFA-625, CFA Laboratory Complex \\
\hline & Tritium emissions from pumped aquifer water \\
\hline \multirow{17}{*}{$\begin{array}{l}\text { Idaho Nuclear } \\
\text { Technology and } \\
\text { Engineering Center } \\
\text { (INTEC): }\end{array}$} & CPP-603-001, Irradiated Fuels Storage Facility \\
\hline & CPP-653-001, EPA Radiological Dispersion Device (RDD) Decontamination \\
\hline & Project \\
\hline & CPP-663-002, Maintenance Building Hot Shop vent \\
\hline & CPP-684-001, Remote Analytical Laboratory \\
\hline & CPP-708-001, Main Stack \\
\hline & CPP-749-001, Spent Fuel Storage Vaults \\
\hline & CPP-1608-001, Manipulator Repair Cell \\
\hline & CPP-1774, Three Mile Island (TMI)-2 Independent Spent Storage Installation \\
\hline & CPP-1778, Sewage Treatment Plant \\
\hline & CPP-1791, INTEC percolation ponds \\
\hline & CPP-2707, dry cask storage pad \\
\hline & CPP88, Undisturbed soils \\
\hline & CPP88, Disturbed soils \\
\hline & $\begin{array}{l}\text { INL Comprehensive Environmental Response, Compensation, and Liability Act } \\
\text { (CERCLA) Disposal Facility Landfill (ICDF) emissions from solid waste } \\
\text { disposal }\end{array}$ \\
\hline & ICDF pond emissions \\
\hline & ICDF treatment operations \\
\hline
\end{tabular}




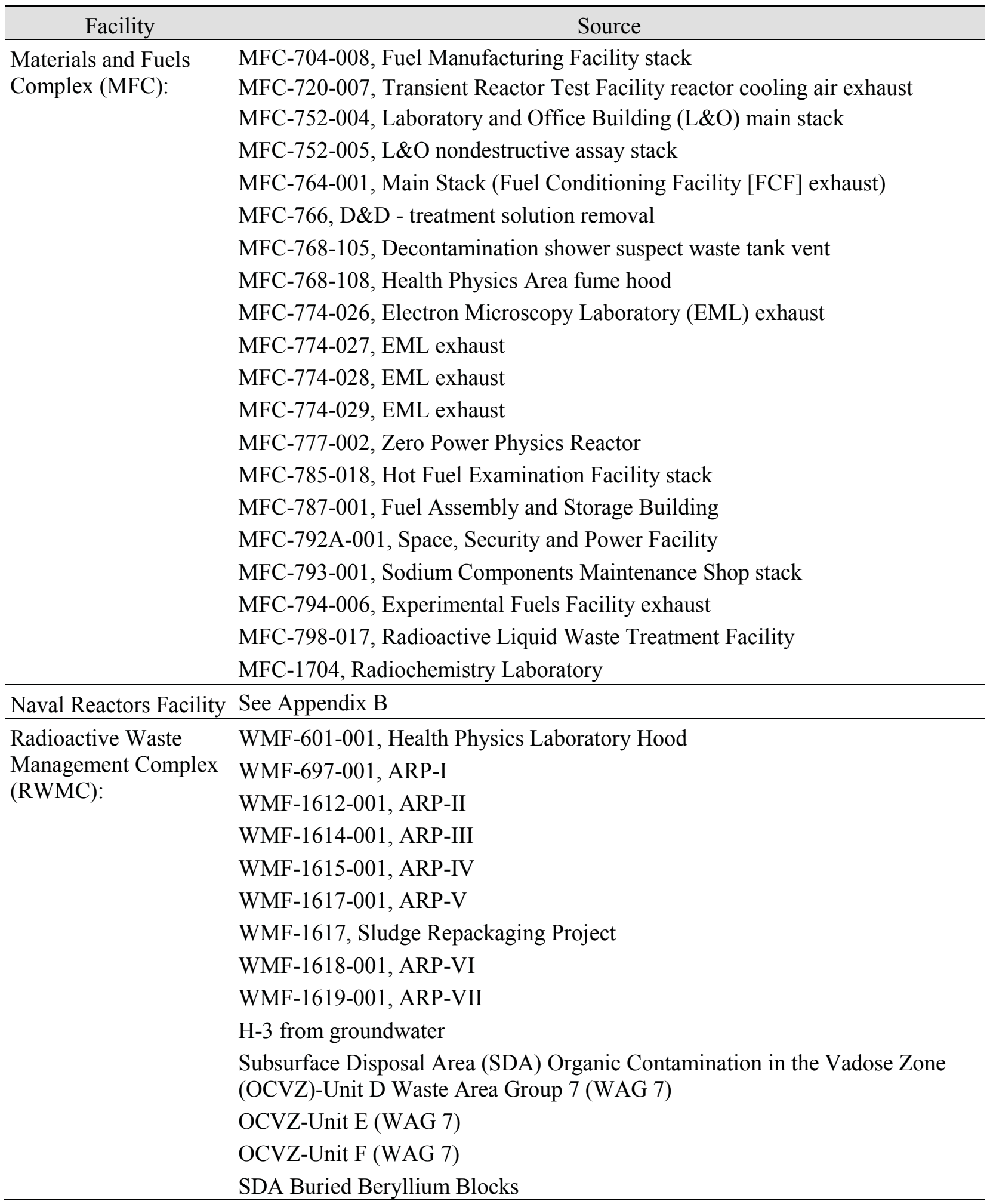


Test Area North (TAN) 629-013, manufacturing process, Line 2A

Specific Manufacturing 679-022, -023, -024 manufacturing process, north process

Capability (SMC):

$679-025,-026,-027$ manufacturing process, south process

681-018, Process Reclamation Facility

681-020, Process Reclamation Facility

TAN Technical Operable Unit (OU) 1-07B, New Pump and Treat Facility

Support Facility (TSF):

40 CFR 61, Subpart H requires DOE facilities to calculate the resulting dose to the offsite MEI. As in previous years, Frenchman's Cabin was the location of INL Site MEI for CY 2012 (see Figure 1). Historically, the calculated EDE for INL has been less than 0.1 millirem (mrem) per year. The EDE to the MEI was $3.57 \mathrm{E}-02 \mathrm{mrem} / \mathrm{yr}$ (3.57 E-07 sievert/yr), which is $0.36 \%$ of the $10-\mathrm{mrem} / \mathrm{yr}$ federal standard and was calculated using all sources that emitted radionuclides to the environment from the INL site. Table 3 provides a summary of INL Site MEI dose by facility and source type. 
Table 3. INL facility dose (mrem) contributions and total INL Site dose (mrem) to the MEI located at Frenchman's Cabin for CY 2012 radionuclide air emissions.

\begin{tabular}{|c|c|c|c|c|}
\hline Facility ID & $\begin{array}{c}\text { Point source } \\
\text { dose (mrem/yr) }\end{array}$ & $\begin{array}{l}\text { Fugitive source } \\
\text { dose (mrem/yr) }\end{array}$ & $\begin{array}{l}\text { Total dose } \\
(\mathrm{mrem} / \mathrm{yr})\end{array}$ & Notes \\
\hline CFA Total & 2.09E-08 & 1.19E-05 & 1.19E-05 & Central Facilities Area \\
\hline INTEC & $5.56 \mathrm{E}-05$ & $9.65 \mathrm{E}-03$ & $9.71 \mathrm{E}-03$ & $\begin{array}{l}\text { Idaho CERCLA Disposal Facility } \\
\text { and other INTEC soils }\end{array}$ \\
\hline INTEC-MS & 8.69E-06 & & 8.69E-06 & INTEC Main Stack \\
\hline INTEC Total & $6.43 E-05$ & $9.65 E-03$ & $9.71 E-03$ & Total from INTEC sources \\
\hline MFC & $1.85 \mathrm{E}-05$ & & $1.85 \mathrm{E}-05$ & Materials and Fuels Complex \\
\hline MFC-MS & 3.81E-09 & & $3.81 \mathrm{E}-09$ & $\begin{array}{l}\text { Materials and Fuels Complex, Main } \\
\text { Stack }\end{array}$ \\
\hline MFC Total & 1.85E-05 & & 1.85E-05 & Total from MFC sources \\
\hline NRF Total & $1.76 \mathrm{E}-04$ & 1.92E-06 & 1.78E-04 & Naval Reactor Facility \\
\hline ATR Complex & $5.27 \mathrm{E}-05$ & $4.53 \mathrm{E}-03$ & $4.59 \mathrm{E}-03$ & ATR Complex \\
\hline ATR Complex-ATR & $5.23 \mathrm{E}-03$ & & $5.23 \mathrm{E}-03$ & $\begin{array}{l}\text { Advanced Test Reactor Main Stack } \\
\text { at ATR Complex }\end{array}$ \\
\hline ATR Complex -MTR & $9.18 \mathrm{E}-05$ & & $9.18 \mathrm{E}-05$ & $\begin{array}{l}\text { Materials Test Reactor at ATR } \\
\text { Complex }\end{array}$ \\
\hline ATR Complex Total & 5.37E-03 & 4.53E-03 & $9.91 \mathrm{E}-03$ & Total from ATR Complex sources \\
\hline AMWTP & $3.25 \mathrm{E}-06$ & & $3.25 \mathrm{E}-06$ & $\begin{array}{l}\text { Advanced Mixed Waste Treatment } \\
\text { Plant (includes WMF-636, WMF- } \\
\text { 634, WMF-628-002, WMF-615) }\end{array}$ \\
\hline RWMC & $1.04 \mathrm{E}-07$ & $1.59 \mathrm{E}-02$ & $1.59 \mathrm{E}-02$ & $\begin{array}{l}\text { Others sources at Radioactive Waste } \\
\text { Management Complex }\end{array}$ \\
\hline RWMC Total & 3.35E-06 & 1.59E-02 & $1.59 \mathrm{E}-02$ & $\begin{array}{l}\text { Total from RWMC sources (Includes } \\
\text { AMWTP) }\end{array}$ \\
\hline TAN-SMC Total & 4.35E-12 & & $4.35 \mathrm{E}-12$ & $\begin{array}{l}\text { Test Area North -Specific } \\
\text { Manufacturing Capability }\end{array}$ \\
\hline TAN-TSF Total & 2.69E-07 & & 2.69E-07 & $\begin{array}{l}\text { Test Area North - Technical } \\
\text { Services Facility }\end{array}$ \\
\hline TOTAL & $5.64 \mathrm{E}-03$ & 3.01E-02 & 3.57E-02 & \\
\hline
\end{tabular}




\section{40 CFR PART 61.94(b) (1)}

"Name and location of the facility."

Site Name: Idaho National Laboratory Site.

Site Location: The INL Site encompasses approximately 890 square miles on the upper Snake River Plain in southeastern Idaho (see Figure 1). The nearest INL boundaries to population centers are approximately $22 \mathrm{mi}(35.3 \mathrm{~km})$ west of Idaho Falls, $23 \mathrm{mi}(37 \mathrm{~km})$ northwest of Blackfoot, $44 \mathrm{mi}$ $(70.8 \mathrm{~km})$ northwest of Pocatello, $7 \mathrm{mi}(11.3 \mathrm{~km})$ east of Arco, $1 \mathrm{mi}(1.6 \mathrm{~km})$ north of Atomic City, $3 \mathrm{mi}$ $(5 \mathrm{~km})$ west of Mud Lake, and $2 \mathrm{mi}(6 \mathrm{~km})$ south of Howe.

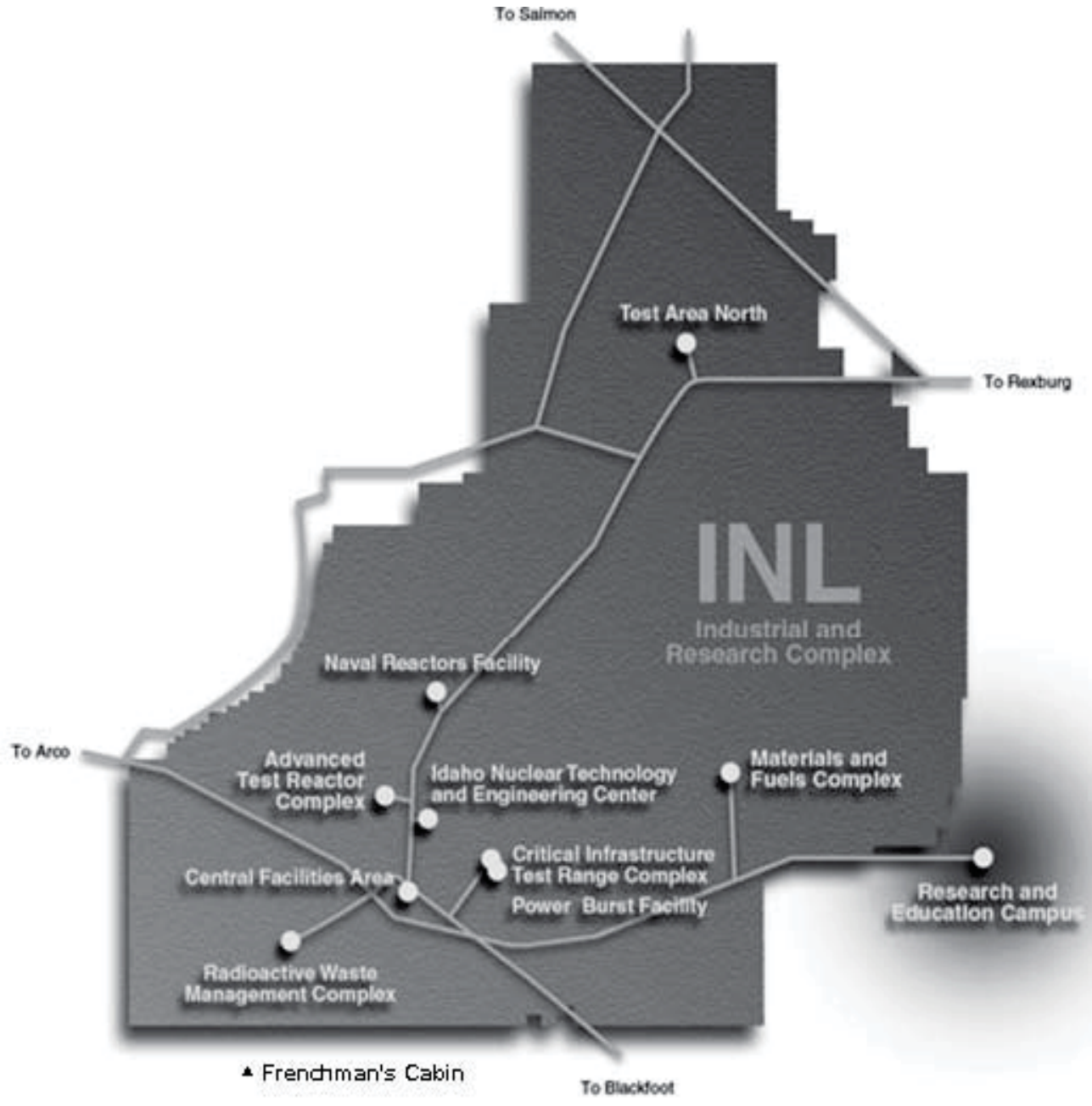

Figure 1. INL Site, including major facility areas and off-site MEI located at Frenchman's Cabin. 


\section{40 CFR PART 61.94(b) (2)}

"A list of the radioactive materials used at the facility."

The individual radionuclides found in materials used at INL Site during CY 2012 are listed in Table 4. These materials included, but were not limited to, samples, products, process solids, liquids, and wastes that have potential emissions.

Table 4. Radionuclides in use and potentially emitted to the atmosphere from INL Site facilities in CY 2012.

\begin{tabular}{|c|c|c|c|c|}
\hline$\overline{\mathrm{Ag}-110 \mathrm{~m}}$ & $\mathrm{Cr}-51$ & $\mathrm{Kr}-88$ & $\mathrm{Pu}-239$ & Tc-99 \\
\hline Am-241 & Cs-134 & La-140 & $\mathrm{Pu}-240$ & Tc-99m \\
\hline Am-242 & Cs-137 & La-142 & $\mathrm{Pu}-241$ & $\mathrm{Te}-123 \mathrm{~m}$ \\
\hline Am-243 & Cs- 138 & Mn-53 & $\mathrm{Pu}-242$ & Тe-129 \\
\hline Ar-39 & $\mathrm{Eu}-152$ & Mn-54 & Ra-224 & Th-228 \\
\hline Ar-41 & Eu-154 & Mn-56 & Ra-226 & Th-229 \\
\hline Ba-133 & Eu-155 & Mo-93 & $\mathrm{Rb}-88$ & Th-230 \\
\hline Ba-137m & Eu-156 & Mo-99 & $\mathrm{Rb}-89$ & Th-232 \\
\hline Ba-139 & $\mathrm{Fe}-55$ & $\mathrm{Na}-22$ & Re-184 & Th-234 \\
\hline Ba-140 & $\mathrm{Fe}-59$ & $\mathrm{Na}-24$ & $\mathrm{Re}-184 \mathrm{~m}$ & Tl-204 \\
\hline Ba-141 & $\mathrm{Fe}-60$ & $\mathrm{Nb}-93 \mathrm{~m}$ & Re-186 & Tl-208 \\
\hline Be-10 & Gd-153 & $\mathrm{Nb}-94$ & Re-186m & U-232 \\
\hline $\mathrm{Be}-7$ & Ge-71 & $\mathrm{Nb}-95$ & Re-187 & U-233 \\
\hline Bi-207 & $\mathrm{H}-3$ & $\mathrm{Nb}-97$ & Re-188 & U-234 \\
\hline $\mathrm{Bi}-210$ & Hf- 175 & $\mathrm{Ni}-59$ & Rh-106 & U-235 \\
\hline $\mathrm{Bi}-210 \mathrm{~m}$ & Hf- $178 \mathrm{~m}$ & $\mathrm{Ni}-63$ & $\mathrm{Ru}-103$ & U-236 \\
\hline $\mathrm{Bi}-212$ & Hf $-179 m$ & $\mathrm{~Np}-237$ & Ru-106 & $\mathrm{U}-238$ \\
\hline $\mathrm{Br}-83$ & Hf- 181 & Np-239 & Sb-122 & $V-49$ \\
\hline C-14 & Hf- 182 & Os- 185 & $\mathrm{Sb}-124$ & W-181 \\
\hline $\mathrm{Ca}-45$ & $\mathrm{Hg}-203$ & Os-191 & Sb-125 & W-185 \\
\hline Cd-109 & Ho- $166 \mathrm{~m}$ & $\mathrm{P}-32$ & Sc-46 & W-187 \\
\hline Ce-139 & I-128 & P-33 & $\mathrm{Si}-32$ & W-188 \\
\hline $\mathrm{Ce}-141$ & I-129 & $\mathrm{Pa}-233$ & Sm-151 & Xe-133 \\
\hline Ce-144 & I-131 & $\mathrm{Pb}-205$ & Sn-113 & Xe-135 \\
\hline $\mathrm{Cl}-36$ & I-132 & $\mathrm{Pb}-210$ & Sr- 85 & $\mathrm{Xe}-135 \mathrm{~m}$ \\
\hline $\mathrm{Cm}-242$ & I-133 & $\mathrm{Pb}-212$ & Sr- 89 & Xe-138 \\
\hline $\mathrm{Cm}-243$ & I-134 & Pm-147 & Sr-90 & Y-88 \\
\hline $\mathrm{Cm}-244$ & I- 135 & Рo-210 & Sr-91 & Y-90 \\
\hline $\mathrm{Cm}-248$ & Ir-192 & Po-212 & Sr-92 & $Y-92$ \\
\hline Co-57 & $\mathrm{K}-40$ & Po- 216 & Тa-179 & $\mathrm{Zn}-65$ \\
\hline $\mathrm{Co}-58$ & $\mathrm{Kr}-85$ & Pr-144 & Ta-180m & $\mathrm{Zr}-95$ \\
\hline Co-60 & $\mathrm{Kr}-85 \mathrm{~m}$ & $\mathrm{Pu}-236$ & Тa-182 & $\mathrm{Zr}-97$ \\
\hline Co-60m & $\mathrm{Kr}-87$ & $\mathrm{Pu}-238$ & Тa-183 & \\
\hline
\end{tabular}




\section{40 CFR PART 61.94(b) (3)}

"A description of the handling and processing that the radioactive materials undergo at the facility."

\subsection{Advanced Mixed Waste Treatment Project}

The AMWTP is located at RWMC and is operated by the Idaho Treatment Group. The AMWTP had nine potential sources of radionuclide emission in operation during CY 2012. Radiological air emissions from the AMWTP may result from the retrieval, characterization, and treatment of transuranic waste, alpha-contaminated low-level mixed waste (alpha LLMW), and LLMW. The mission of the AMWTP is to produce final waste forms that are certified for disposal. These sources were modeled together with RWMC sources (Section 5.6).

\subsection{Advanced Test Reactor Complex}

The ATR Complex is operated by Battelle Energy Alliance, LLC (BEA) and is located in the south central section of INL. The ATR Complex has facilities for studying the performance of reactor materials and equipment components under high neutron flux conditions. The major facility at ATR Complex is the ATR. Other operations at ATR Complex include research and development, site remediation, and analytical laboratory services.

Radiological air emissions from ATR Complex are primarily associated with operation of the ATR. These emissions include noble gases, iodines, and other mixed fission and activation products. Other radiological air emissions are associated with sample analysis, site remediation, and research and development activities.

\subsection{Central Facilities Area}

The Central Facilities Area (CFA) is located in the south-central section of INL Site. The CFA provides services that support the following INL Site facilities:

Maintenance shops

Vehicle maintenance facilities

Instrument calibration laboratories

Communications and security systems

Fire protection

Medical services

Warehouses

Laboratory Facilities

Other support services facilities

Minor emissions occur from CFA facilities where work with small quantities of radioactive materials is routinely conducted. This includes sample preparation and verification and radiochemical research and development. Other minor emissions result from groundwater usage. 


\subsection{Idaho Nuclear Technology and Engineering Center}

The Idaho Nuclear Technology and Engineering Center (INTEC) is located in the southern portion of the INL. As its primary mission, it began operations in 1953 to recover and reprocess spent nuclear fuel. It was operated for Department of Energy Idaho Operations Office (DOE-ID) by CWI for the CY2012 reporting period.

Radiological air emissions from INTEC sources are primarily associated with liquid waste operations, including effluents from the Tank Farm Facility, Process Equipment Waste Evaporator, and Liquid Effluent Treatment and Disposal, which are exhausted through the Main Stack. These radioactive emissions include particulates and gaseous radionuclides. Additional radioactive emissions are associated with decontamination and debris treatment operations; wet-to-dry spent nuclear fuel movements, remotehandled transuranic waste management, radiological and hazardous waste storage facilities, and contaminated equipment maintenance.

The Idaho CERCLA Disposal Facility is located on the southwest corner of INTEC. Radiological emissions from this facility are estimated from waste disposal in the landfill, evaporation pond operations, and waste treatment operations.

BEA reported minor radioactive emissions from the EPA RDD Decontamination Project located in CPP-653.

\subsection{Materials and Fuels Complex}

The Materials and Fuels Complex (MFC) is located in the southeastern corner of INL Site. MFC, a research facility operated by BEA, is involved in advanced nuclear power research and development, spent fuel and waste treatment technologies, national security programs, and projects to support space exploration.

Radiological air emissions are primarily associated with spent fuel treatment at the FCF, waste characterization at the Hot Fuel Examination Facility (HFEF) and fuel research and development at the Fuel Manufacturing Facility (FMF). These facilities are equipped with continuous emission monitoring (CEM) systems. On a regular basis, the effluent streams from FCF, HFEF, FMF and other non-CEM radiological facilities are sampled and analyzed for particulate radionuclides. Gaseous and particulate radionuclides may also be released from other MFC facilities during laboratory research activities, sample analysis, waste handling and storage, and maintenance operations. Both measured and estimated emissions from MFC sources are consolidated for National Emission Standards for Hazardous Air Pollutants (NESHAP) reporting on an annual basis.

Radiological emissions are estimated from CWI D\&D activities that occurred in 2012 in MFC-766, Sodium Boiler Building.

\subsection{Radioactive Waste Management Complex}

The RWMC, located in the southwestern corner of INL, is a controlled-access area with a primary mission to manage the low-level radioactive site and to temporarily store contact-handled and remotehandled transuranic waste that will be shipped to other designated facilities for disposal. In addition, various activities are being conducted in the Subsurface Disposal Area at the RWMC to complete environmental cleanup of the area under CERCLA. These include waste retrieval activities (Accelerated Retrieval Projects [ARP]), and operation of several units that extract volatile organic compounds from the subsurface. 
Potential unabated emissions from the ARP exceed $0.1 \mathrm{mrem} / \mathrm{yr}$. By agreement with EPA, the ARP used ambient air monitoring as an alternative to air dispersion calculations to verify compliance with the standard during ARP operation. Therefore, record sampling is not performed, although continuous air monitors are used for real-time monitoring for detection of off-normal emissions.

Prior to November 20,2012, the RWMC processed (sort and repackage) radionuclide contaminated soils and sludge within the ARP-V enclosure, and after November 20 sludge from the AMWTP facility was processed at WMF-1617 (ARP-V enclosure). The AMWTP sludge processing activity is designed to ensure contact-handled stored transuranic waste is compliant with off-site disposal facility waste acceptance criteria by removing prohibited waste items (e.g., free liquids). The vented releases from the enclosures are released through high-efficiency particulate air (HEPA)-filtered vents. Radionuclide emissions from the ARP enclosures, including sludge processing at WMF-1617 are calculated for use with emissions measurements from other INL sources to demonstrate INL site-wide compliance using the CAP88-PC Version 3 model.

\subsection{Test Area North}

TAN is the northernmost developed area within INL. It was originally established to support the Aircraft Nuclear Propulsion Program, which operated from 1951 to 1961. Since 1961, TAN buildings have been adapted for use by various other programs, including current BEA operations at the Specific Manufacturing Capability (SMC) facility.

\subsubsection{Specific Manufacturing Capability}

The TAN-SMC Project, managed by BEA, is a manufacturing operation that produces an armor package for the U.S. Department of the Army. The TAN-SMC Project was assigned to INL Site in mid1983. Operations at TAN-SMC include material development, fabrication, and assembly work to produce armor packages. The operation uses standard metal-working equipment in fabrication and assembly. Other activities include developing tools and fixtures and preparing and testing metallurgical specimens. Radiological air emissions from TAN-SMC are associated with processing of depleted uranium. Potential emissions are uranium isotopes and associated radioactive progeny.

\subsubsection{New Pump and Treat Facility}

The main purpose of the New Pump and Treat Facility (NPTF) located at TAN-TSF is to reduce concentrations of TCE and other volatile organic compounds (VOCs) in the medial zone portion of the OU 1-07B contamination groundwater plume at TAN to below drinking water standards. Low levels of Sr-90 and H-3 are also present in the treated water and are released to the atmosphere by the treatment process. The NPTF is operated by CWI. 


\section{40 CFR PART 61.94(b) (4) and (5)}

"A list of the stacks or vents or other points where radioactive materials are released to the atmosphere. A description of the effluent controls that are used on each stack, vent, or other release point and an estimate of the efficiency of each control device."

Tables 5 through 12 list the facility stacks, vents, or other points where radioactive materials were released to the atmosphere during CY 2012.

Table 5. Stacks, vents, or other points of radioactive materials release to the atmosphere at AMWTP.

\begin{tabular}{|c|c|c|c|c|}
\hline Bldg & Vent & Source Description & Effluent Control Description & Efficiency \\
\hline 615 & 001 & Drum Vent Facility & One HEPA filter & $99.97 \%$ \\
\hline 628 & 002 & Drum Treatment Facility & Two HEPA filters in series & $99.97 \%$ each \\
\hline \multirow[t]{3}{*}{634} & 001 & Characterization Facility & & \\
\hline & & Drum Vent & Two HEPA filters in series & $99.97 \%$ each \\
\hline & & Drum Coring & Three HEPA filters in series & $99.97 \%$ each \\
\hline 636 & 001 & $\begin{array}{l}\text { Transuranic Storage Area- } \\
\text { Retrieval Enclosure (TSA-RE) }\end{array}$ & None & NA \\
\hline \multirow[t]{2}{*}{636} & 002 & RCE Stack & Two HEPA filters in series & $99.97 \%$ each \\
\hline & & ICE Stack & Three HEPA filters in series & $99.97 \%$ each \\
\hline 676 & 002 & Zone 3 Stack & Three HEPA filters in series & $99.97 \%$ each \\
\hline 676 & 003 & Glovebox Stack & Three HEPA filters in series & $99.97 \%$ each \\
\hline TR-14 & 001 & Laboratory Vent & One HEPA filter & $99.97 \%$ \\
\hline TR-14 & 002 & Laboratory Vent & One HEPA filter & $99.97 \%$ \\
\hline
\end{tabular}

Table 6. Stacks, vents, or other points of radioactive materials release to the atmosphere at ATR Complex.

\begin{tabular}{|c|c|c|c|c|}
\hline Bldg & Vent & Source Description & Effluent Control Description & Efficiency \\
\hline 670 & 074 & Laboratory 124 fume hoods exhaust & HEPA filter & $99.97 \%$ \\
\hline 670 & 086 & Laboratory 131 fume hoods exhaust & HEPA filter & $99.97 \%$ \\
\hline 670 & 098 & $\begin{array}{l}\text { Laboratory } 103 \text { fume hoods exhaust } \\
\text { (two hoods) }\end{array}$ & HEPA filter & $99.97 \%$ \\
\hline 670 & NA & ATR Canal & NA & NA \\
\hline 678 & 001 & $\begin{array}{l}\text { Radiation Measurements Laboratory } \\
\text { fume hoods vent }\end{array}$ & HEPA Filter & $99.97 \%$ \\
\hline 710 & 001 & MTR Stack & Partial HEPA filtered ${ }^{\mathrm{a}}$ & $99.97 \%$ \\
\hline 770 & 001 & ATR Main Stack & NA & NA \\
\hline 1627 & 001 & $\begin{array}{l}\text { Radioanalytical Chemistry } \\
\text { Laboratory fume hoods stack }\end{array}$ & HEPA Filter & $99.97 \%$ \\
\hline
\end{tabular}

a. HEPA filters are on the effluent from the Safety and Tritium Applied Research Facility (TRA-666) prior to being emitted from the MTR stack.

Table 7. Stacks, vents, or other points of radioactive materials release to the atmosphere at CFA.

\begin{tabular}{ccccc}
\hline Bldg & Vent & Source Description & Effluent Control Description $^{\text {a }}$ & Efficiency \\
\hline 625 & 010 & Laboratory fume hoods & HEPA Filter bank & $99.97 \%$ \\
& & & \\
\hline \multicolumn{2}{l}{ a. Bank includes multiple HEPA filters. } & & \\
\hline
\end{tabular}


Table 8. Stacks, vents, or other points of radioactive materials release to the atmosphere at INTEC.

\begin{tabular}{cclll}
\hline Bldg & Vent & \multicolumn{1}{c}{ Source Description } & Effluent Control Description & Efficiency \\
\hline 603 & 001 & Irradiated Fuel Storage Facility & Two HEPA filters in series & $99.97 \%$ each \\
659 & 033 & NWCF Stack & HEPA Filter & $99.97 \%$ \\
663 & 002 & Maintenance building hot shop vent & HEPA filter & $99.97 \%$ \\
684 & 001 & Remote Analytical Laboratory & Two HEPA filters in series & $99.97 \%$ each \\
708 & 001 & INTEC Main Stack & Up to three HEPA filters in & $99.97 \%$ each \\
& & series & HEPA filter or two HEPA & $99.97 \%$ each \\
767 & 001 & FAST Stack & filters in series & \\
& & Two HEPA filters in series & $99.97 \%$ each \\
1608 & 001 & Manipulator Repair Cell & $99 \%$ \\
1774 & NA & TMI-2 Independent Spent Fuel Storage HEPA filter & \\
& & &
\end{tabular}

Table 9. Stacks, vents, or other points of radioactive materials released to the atmosphere at MFC.

\begin{tabular}{|c|c|c|c|c|}
\hline Bldg & Vent & Source Description & Effluent Control Description $^{a}$ & Efficiency \\
\hline 704 & 008 & Fuel Manufacturing Facility stack & Two HEPA filter banks in series & $99.97 \%$ each \\
\hline 720 & 007 & $\begin{array}{l}\text { Transient Reactor Test Facility } \\
\text { reactor cooling air exhaust }\end{array}$ & Two HEPA filter banks in series & $99.97 \%$ each \\
\hline 752 & 004 & L\&O Building main stack & Two HEPA filter banks in series & $99.97 \%$ each \\
\hline 752 & 005 & $\begin{array}{l}\text { L\&O Building nondestructive assay } \\
\text { building stack }\end{array}$ & $\begin{array}{l}\text { One to four HEPA filters in } \\
\text { series }\end{array}$ & $99.97 \%$ each \\
\hline 764 & 001 & FCF Main Stack & Two HEPA filter banks & $99.97 \%$ each \\
\hline 766 & 001 & MFC-799 Tank Treatment & HEPA filter bank & $99.97 \%$ each \\
\hline 768 & 105 & $\begin{array}{l}\text { Decontamination shower suspect } \\
\text { waste tank vent }\end{array}$ & HEPA filter bank & $99.97 \%$ \\
\hline 768 & 108 & Health Physics area fume hoods & HEPA filter bank & $99.97 \%$ \\
\hline \multirow[t]{4}{*}{774} & 026 & EML exhaust & Two HEPA filter banks in series & $99.97 \%$ each \\
\hline & 027 & EML exhaust & Two HEPA filter banks in series & $99.97 \%$ each \\
\hline & 028 & EML exhaust & Two HEPA filter banks in series & $99.97 \%$ each \\
\hline & 029 & EML exhaust & Two HEPA filter banks in series & $99.97 \%$ each \\
\hline 777 & 002 & Zero Power Physics Reactor exhaust & Two HEPA filter banks in series & $99.97 \%$ each \\
\hline 785 & 018 & Hot Fuel Examination Facility stack & Two HEPA filter banks in series & $99.97 \%$ each \\
\hline 787 & 001 & $\begin{array}{l}\text { Fuel Assembly and Storage } \\
\text { Building }\end{array}$ & HEPA filter bank & $99.97 \%$ \\
\hline $792 \mathrm{~A}$ & 001 & Space, Security and Power Facility & Two HEPA filter banks in series & $99.97 \%$ each \\
\hline 793 & 001 & $\begin{array}{l}\text { Sodium Components Maintenance } \\
\text { Shop stack }\end{array}$ & HEPA filter bank & $99.97 \%$ \\
\hline 794 & 006 & Experimental Fuels Facility exhaust & HEPA filter bank & $99.97 \%$ \\
\hline 798 & 017 & $\begin{array}{l}\text { Radioactive Liquid Waste } \\
\text { Treatment Facility }\end{array}$ & HEPA filter bank & $99.97 \%$ \\
\hline 1704 & NA & Radiochemistry Laboratory & HEPA filter bank & $99.97 \%$ \\
\hline
\end{tabular}


Table 10. Stacks, vents, or other points of radioactive materials release to the atmosphere at RWMC.

\begin{tabular}{ccllc}
\hline Bldg & Vent & \multicolumn{1}{c}{ Source Description } & Effluent Control Description & Efficiency \\
\hline 601 & 001 & Health Physics Laboratory Hood & HEPA filter & $99.97 \%$ \\
697 & 001 & ARP-I & HEPA filter & $99.97 \%$ \\
1612 & 001 & ARP-II & HEPA filter & $99.97 \%$ \\
1614 & 001 & ARP-III & HEPA filter & $99.97 \%$ \\
1615 & 001 & ARP-IV & HEPA filter & $99.97 \%$ \\
1617 & 001 & ARP-V and Sludge Repackage Project & HEPA filter \\
1618 & 001 & ARP-VI & HEPA filter & $99.97 \%$ \\
1619 & 001 & ARP-VII & HEPA filter & $99.97 \%$ \\
SDA & 1 & Organic Contaminated Vadose Zone & NA & $99.97 \%$ \\
& & (OCVZ)-Unit D (WAG-7) & & NA \\
SDA & 1 & OCVZ-Unit E (WAG-7) & NA & NA \\
SDA & 1 & OCVZ-Unit F (WAG-7) & NA & NA \\
\hline
\end{tabular}

Table 11. Stacks, vents, or other points of radioactive materials release to the atmosphere at TAN-SMC.

\begin{tabular}{|c|c|c|c|c|}
\hline Bldg & Vent & Source Description & Effluent Control Description $^{a}$ & Efficiency \\
\hline 629 & 013 & Line 2 , manufacturing process & Two HEPA filter banks & $99.97 \%$ \\
\hline 679 & 022 & $\begin{array}{l}\text { North process (RAD Stack \#11) } \\
\text { manufacturing process (EF-206) } \\
\text { and includes releases from the } \\
\text { quality control (QC) laboratory }\end{array}$ & HEPA filter bank & $99.97 \%$ \\
\hline 679 & 023 & $\begin{array}{l}\text { North process (RAD Stack \#10) } \\
\text { manufacturing process (EF-205) } \\
\text { and includes releases from the QC } \\
\text { laboratory }\end{array}$ & HEPA filter bank & $99.97 \%$ \\
\hline 679 & 024 & $\begin{array}{l}\text { North process (RAD Stack \#9) } \\
\text { manufacturing process (EF-204) } \\
\text { and includes releases from the QC } \\
\text { laboratory }\end{array}$ & HEPA filter bank & $99.97 \%$ \\
\hline 679 & 025 & $\begin{array}{l}\text { South process (RAD Stack \#8) } \\
\text { manufacturing process (EF-203) }\end{array}$ & HEPA filter bank & $99.97 \%$ \\
\hline 679 & 026 & $\begin{array}{l}\text { South process (RAD Stack \#7) } \\
\text { manufacturing process (EF-202) }\end{array}$ & HEPA filter bank & $99.97 \%$ \\
\hline 679 & 027 & $\begin{array}{l}\text { South process (RAD Stack \#6) } \\
\text { manufacturing process (EF-201) }\end{array}$ & HEPA filter bank & $99.97 \%$ \\
\hline 681 & 018 & Process Reclamation Facility & HEPA filter bank & $99.97 \%$ \\
\hline 681 & 020 & Process Reclamation Facility & HEPA filter bank & $99.97 \%$ \\
\hline
\end{tabular}

Table 12. Stacks, vents, or other points of radioactive materials release to the atmosphere at TAN-TSF.

\begin{tabular}{ccccc}
\hline Bldg. & Vent & Source Description & Effluent Control Description & Efficiency \\
\hline NA & & OU 1-07B Treatment Process & NA & NA \\
\hline
\end{tabular}




\section{40 CFR PART 61.94(b) (6)}

"List distances from the points of release to the nearest residence, school, business or office and the nearest farms producing vegetables, milk, and meat."

Table 13 shows distances from the points of release to the nearest residence, school, business or office, and the nearest farms producing vegetables, milk, and meat.

Table 13. Distances from INL facility points of release to the nearest off-Site receptor location and to Frenchman's Cabin (INL MEI).

\begin{tabular}{|c|c|c|}
\hline Facility & $\begin{array}{c}\text { Distance and Direction to Nearest } \\
\text { Residence, School, Farm, or Business }\end{array}$ & $\begin{array}{l}\text { Distance and Direction to } \\
\text { Frenchman's Cabin }\end{array}$ \\
\hline MFC & $8,678 \mathrm{~m}^{\mathrm{a}} \mathrm{SSE}$ & $37,219 \mathrm{~m} \mathrm{WSW}$ \\
\hline CFA & $12,453 \mathrm{~m} \mathrm{SE}$ & $14,359 \mathrm{~m} \mathrm{SW}$ \\
\hline INTEC & $15,333 \mathrm{~m} \mathrm{SSE}$ & $18,718 \mathrm{~m} \mathrm{SSW}$ \\
\hline NRF & $13,714 \mathrm{~m} \mathrm{NNW}$ & $26,675 \mathrm{~m} \mathrm{SSW}$ \\
\hline RWMC/AMWTP & 7,976 m SSW & 7,976 m SSW \\
\hline TAN-TSF & $10,344 \mathrm{~m} \mathrm{E}$ & $54,611 \mathrm{~m} \mathrm{SSW}$ \\
\hline TAN-SMC & $12,298 \mathrm{~m} \mathrm{E}$ & $54,405 \mathrm{~m} \mathrm{SSW}$ \\
\hline ATR Complex & $17,421 \mathrm{~m} \mathrm{NW}$ & $19,172 \mathrm{~m} \mathrm{SSW}$ \\
\hline
\end{tabular}




\section{40 CFR PART 61.94(b) (7)}

"The values used for all other user-supplied input parameters for the computer models (e.g. meteorological data) and the source of these data."

Tables 14 and 15 show the CAP-88 modeling input parameters for CY 2012.

Table 14. Description of data tables in NESHAP CAP88 database

\begin{tabular}{lll}
\hline \multicolumn{1}{c}{ Table Name } & \multicolumn{1}{c}{ Field Name } & \multicolumn{1}{c}{ Description } \\
\hline UnitDoses & FacilityID & Facility Identification (see Table 15) \\
& Nuclide & Nuclide name \\
& Direction & Direction to MEI \\
& Distance & Distance to MEI \\
& UDose & Unit dose (mrem/Ci) \\
Releases & SourceID & Source Identification \\
& FacilityID & Facility Identification (see Table 15) \\
& Fugitive & Fugitive or Non-Fugitive release flag \\
& Radionuclide & Nuclide name \\
MkMEIsBySecName & FacilityID & Release rate (Ci/yr) \\
& SectorName & Facility Identification (see Table 15) \\
& Distance & Text name of the 16, 22.5-degree sectors \\
& ReceptorNum & Distance from the facility to the receptor \\
& Receptor number index \\
\hline
\end{tabular}

a. The receptor number is the identification assigned to the 62 receptors surrounding INL. The distance and direction to each receptor varies by facility.

Table 15. INL Site meteorological files and wind measurements heights.

\begin{tabular}{|c|c|c|c|}
\hline Facility & Facility ID & Wind File & $\begin{array}{c}\text { Measurement } \\
\text { Height (m) }\end{array}$ \\
\hline Central Facilities Area & CFA & 690L12.WND & 10 \\
\hline Idaho Nuclear Technology and & INTEC & GRIL12.WND & 10 \\
\hline Engineering Center, Idaho CERCLA & & & \\
\hline Disposal Facility & & & \\
\hline $\begin{array}{l}\text { Idaho Nuclear Technology and } \\
\text { Engineering Center - Main Stack }\end{array}$ & INTEC-MS & GRIU12.WND & 30 \\
\hline Materials and Fuels Complex & MFC & EBRL12.WND & 10 \\
\hline $\begin{array}{l}\text { Materials and Fuels Complex Main } \\
\text { Stack }\end{array}$ & MFC-MS & EBRU12.WND & 30 \\
\hline Naval Reactors Facility & NRF & NRFL12.WND & 10 \\
\hline Advanced Test Reactor Complex & ATR Complex & TRAL12.WND & 10 \\
\hline $\begin{array}{l}\text { Advanced Test Reactor Complex- } \\
\text { Advanced Test Reactor }\end{array}$ & ATR Complex - ATR & GRIU12.WND & 30 \\
\hline $\begin{array}{l}\text { Advanced Test Reactor Complex- } \\
\text { Materials Test Reactor }\end{array}$ & ATR Complex -MTR & GRIU12.WND & 30 \\
\hline $\begin{array}{l}\text { Radioactive Waste Management } \\
\text { Complex }\end{array}$ & RWMC & RWMCL12.WND & 10 \\
\hline $\begin{array}{l}\text { Test Area North - Specific } \\
\text { Manufacturing Capability }\end{array}$ & $\mathrm{SMC}$ & LOFL12.WND & 10 \\
\hline $\begin{array}{l}\text { Test Area North - Technical Support } \\
\text { Facility }\end{array}$ & TAN-TSF & LOFL12.WND & 10 \\
\hline
\end{tabular}




\section{40 CFR PART 61.94(b) (8)}

"A brief description of all construction and modifications which were completed in the calendar year for which the report is prepared, but for which the requirement to apply for approval to construct or modify was waived under $\$ 61.96$ and associated documentation developed by DOE to support the waiver. EPA reserves the right to require that DOE send to EPA all the information that normally would be required in an application to construct or modify, following receipt of the description and supporting documentation"

During calendar year 2012, the RWMC began processing organic sludges from the AMWTP facility in WMF-1617. The sludge processing activity is designed to ensure contact-handled stored transuranic waste is compliant with off-site disposal facility waste acceptance criteria by removing prohibited waste items (e.g., free liquids). The project is being conducted in accordance with an approved RCRA permit and results in minor particulate emissions released through HEPA-filtered vents. Radiological release and dose calculations show the total abated dose is $0.029 \mathrm{mrem} / \mathrm{yr}$, which is below the 0.1 -mrem threshold for requiring an application for approval to construct. 


\section{Appendix A}

INL Research and Education Complex 


\section{Appendix A}

\section{INL Research and Education Complex}

This report documents radionuclide air emissions for calendar year (CY) 2012 and the resulting effective dose equivalent (EDE) to the maximally exposed individual (MEI) member of the public from operations at Idaho National Laboratories (INL) at the INL Research Center (IRC) and the Department of Energy - Idaho Operations Office (DOE-ID) Radiological and Environmental Sciences Laboratory (RESL) on the INL Research and Education Complex (REC).

The heading of each section in this report corresponds to the citation found in 40 Code of Federal Regulations (CFR) Part 61.94. The applicable reporting requirement is cited under the heading in italicized text followed by the compliance report for REC.

\section{CFR 61.94(a)}

"Compliance with this standard shall be determined by calculating the highest effective dose equivalent to any member of the public at any offsite point where there is a residence, school, business or office. The owners or operators of each facility shall submit an annual report to both Environmental Protection Agency (EPA) headquarters and the appropriate regional office by June 30, which includes the results of the monitoring as recorded in DOE's Effluent Information System and the dose calculations required by $\$ 61.93($ a) for the previous calendar year."

This appendix documents radionuclide air emissions for calendar year (CY) 2012 and the resulting effective dose equivalent (EDE) to the maximally exposed individual (MEI) member of the public from operations at the REC.

For CY 2012, modeling was performed using Clean Air Act Assessment Package (CAP)-88PC, Version 3.

No radionuclide emissions for the IRC or RESL required continuous monitoring for compliance during CY 2012. Table 1A lists the sources used to calculate the EDE to the MEI.

Table 1A. Sources used to calculate the EDE to the MEI.

\begin{tabular}{ll}
\hline Facility & Source \\
\hline IRC: & IF-603, IRC Laboratory (IRC-L) Building \\
& IF-611, National Security Laboratory \\
& IF-638, IRC Physics Laboratory \\
\hline RESL: & IF-683, Radiological and Environmental Sciences Laboratories \\
\hline
\end{tabular}

40 CFR 61, Subpart H requires DOE facilities to calculate the resulting dose to the offsite MEI. The location of IRC MEI for CY 2012 is 100 meters south of the IRC. The EDE to the MEI was 9.12E-03 $\mathrm{mrem} / \mathrm{yr}(9.12 \mathrm{E}-08$ sievert/yr), which is $0.091 \%$ of the $10-\mathrm{mrem} / \mathrm{yr}$ federal standard and was calculated using all sources that emitted radionuclides to the environment from the REC. Table 2A provides a summary of REC MEI dose by facility and source type. 
Table 2A, Dose (mrem) contributions and total IRC dose (mrem) to the MEI located $0.1 \mathrm{~km}$ south of the IRC for CY 2012 radionuclide air emissions.

\begin{tabular}{lrccc}
\hline Facility ID & $\begin{array}{c}\text { Point source } \\
\text { dose }(\mathrm{mrem} / \mathrm{yr})\end{array}$ & $\begin{array}{c}\text { Fugitive source } \\
\text { dose }(\mathrm{mrem} / \mathrm{yr})\end{array}$ & $\begin{array}{c}\text { Total dose } \\
(\mathrm{mrem} / \mathrm{yr})\end{array}$ & \multicolumn{1}{c}{ Notes } \\
\hline IRC Total & $2.06 \mathrm{E}-03$ & None & $2.06 \mathrm{E}-03$ & BEA IRC sources \\
& $7.06 \mathrm{E}-03$ & None & $7.06 \mathrm{E}-03$ & DOE RESL sources \\
RESL Total & $9.12 \mathrm{E}-03$ & & $9.12 \mathrm{E}-03$ & \\
\cline { 2 - 5 } TOTAL & & &
\end{tabular}

\section{CFR 61.94(b)}

"In addition to paragraph (a), the annual report will include the following information:"

\section{CFR 61.94(b)(1)}

"The name and location of the facility."

IRC and RESL facilities are located on a partially developed 14.3-ha (35.5-acre) plot on the north side of the City of Idaho Falls. Though programs and operations at the IRC are affiliated with INL, the IRC is located within the city limits of Idaho Falls and is not contiguous with INL Site, the nearest boundary of which is approximately $22 \mathrm{mi}$ west of Idaho Falls.

The IRC consists of one-story laboratory buildings containing 66 laboratories (Bldg IF-603), the National Security Laboratory (Bldg IF-611) and IRC Physics Lab (Bldg IF-638). RESL (Bldg IF-683) consists of 8 radiochemistry laboratories, stable chemistry laboratories, offices, and conference areas. 


\section{CFR 61.94(b)(2)}

"A list of the radioactive materials used at the facility."

The individual radionuclides found in materials used at the IRC and RESL during CY 2012 are listed in Table 3A. These materials included, but were not limited to, samples, products, process solids, liquids, and wastes that have potential emissions.

Table 3A. Radionuclides in use and potentially emitted to the atmosphere from REC facilities in CY 2012.

\begin{tabular}{llllll}
\hline Ag-108m & Co-58 & I-129 & Pd-103 & Se-75 & Te-131m \\
Ag-110m & Co-60 & I-131 & Pm-145 & Se-79 & Th-228 \\
Am-241 & Co-60m & In-114m & Pm-147 & Sm-145 & Th-230 \\
Ar-37 & Cr-51 & Ir-192m & Pm-148 & Sm-151 & Th-232 \\
Ar-39 & Cs-131 & Ir-194 & Pm-148m & Sm-153 & Tl-204 \\
As-76 & Cs-134 & K-40 & Pm-149 & Sn-113 & Tm-170 \\
As-77 & Cs-135 & Kr-81 & Pm-151 & Sn-117m & Tm-171 \\
Au-199 & Cs-136 & Kr-85 & Po-210 & Sn-119m & U-232 \\
Ba-131 & Cs-137 & La-140 & Pr-143 & Sn-121 & U-233 \\
Ba-133 & Cu-67 & Lu-177m & Pt-191 & Sn-121m & U-234 \\
Ba-133m & Er-169 & Mn-54 & Pt-193 & Sn-123 & U-235 \\
Ba-135m & Er-172 & Mo-93 & Pt-195m & Sn-125 & U-236 \\
Be-10 & Eu-152 & Mo-99 & Pu-238 & Sr-85 & U-238 \\
Bi-210 & Eu-152m & Nb-92 & Pu-239 & Sr-89 & W-181 \\
Br-82 & Eu-154 & Nb-94 & Ra-226 & Sr-90 & Xe-129m \\
C-14 & Eu-155 & Nb-95 & Rb-86 & Ta-182 & Xe-131m \\
Ca-45 & Eu-156 & Nb-95m & Re-186 & Ta-183 & Xe-133 \\
Ca-47 & Fe-55 & Nd-147 & Rh-105 & Tb-157 & Xe-133m \\
Cd-109 & Fe-59 & Ni-59 & Ru-103 & Tb-160 & Xe-135 \\
Cd-115 & Gd-153 & Ni-63 & Ru-106 & Tb-161 & Y-90 \\
Cd-115m & Ge-71 & Ni-66 & Ru-97 & Tc-97m & Y-91 \\
Ce-137m & H-3 & Np-237 & S-35 & Tc-99 & Yb-175 \\
Ce-139 & Hf-175 & Os-185 & Sb-122 & Tc-99m & Zn-65 \\
Ce-141 & Hf-179m & Os-191 & Sb-124 & Te-121 & Zr-89 \\
Ce-143 & Hf-181 & Os-193 & Sb-125 & Te-121m & Zr-95 \\
Ce-144 & Hg-197 & Os-194 & Sb-126 & Te-123m & \\
Cl-36 & Hg-203 & P-32 & Sc-46 & Te-125m & Te-127m \\
Cm-244 & Ho-163 & P-33 & Sc-47 & Te-129m & \\
Co-57 & I-125 & Pa-231 & Sc-48 & &
\end{tabular}

\section{CFR 61.94(b)(3)}

"A description of the handling and processing that the radioactive materials undergo at the facility."

The IRC is principally an experimental research facility dedicated to a wide range of research areas, including microbiology; geochemistry; materials characterization; welding; ceramics; thermal fluids behavior; materials testing; nondestructive evaluation of materials using standard industrial x-ray processes, x-ray diffraction, and x-ray fluorescence; analytical and environmental chemistry; and biotechnology. Non-research activities include analytical chemistry and preparation of reference radioactive and nonradioactive standards for evaluation programs. 
The RESL is a federally-owned and operated laboratory by the Department of Energy (DOE). The laboratory's focus is primarily in analytical chemistry, radiation protection, and as a reference laboratory for numerous performance evaluation programs. RESL emissions are from low-level radiological performance testing sample preparation and verification.

\section{CFR 61.94(b)(4)}

"A list of the stacks or vents or other points where radioactive materials are released to the atmosphere."

Tables 4A and 5A list the facility stacks, vents, or other points where radioactive materials were released to the atmosphere during CY 2012.

Radiological emissions from the IRC could arise from uncontrolled laboratory fume hoods within the facility. Exhaust from most of the fume hoods is released directly to the outside atmosphere via the heat recovery fan system of the IRC heating, ventilating, and air conditioning system. The heat recovery fan system exhausts to the outside via vents on the north side of the mechanical penthouse on top of the IRC laboratory building. Stack height of these vents is $7.6 \mathrm{~m}(25 \mathrm{ft})$. The exhausts from other fume hoods (not exhausted to the heat recovery fan) are released to the atmosphere via a $2.1-\mathrm{m}(7.0-\mathrm{ft})$ stack above the roof or two $8.5-\mathrm{m}(28-\mathrm{ft})$ stacks above the roof.

Emissions can occur from other areas as well. Not all radiological emissions will occur from work in a fume hood. Some work is done on work benches or in bay areas.

Radiological emissions from the DOE RESL could be emitted from uncontrolled laboratory fume hoods. These potential emissions are from low-level radiological performance test sample preparation and verification. The fume hoods are identified by vent numbers and the emissions exhaust directly to the outside atmosphere via individual stacks on the south side of the building roof. These stacks all have a height of 9.6m (31.6ft). Radiological emissions from RESL could also be emitted from the centralized building exhaust system located in all the south labs plus the following rooms: Alpha and Gamma Spectrometry, Beta Counting, Radiological Standards Vault, and the Sample and Radiological Storage. The stack height for the centralized exhaust system is $7.4 \mathrm{~m}(24.3 \mathrm{ft})$ and is located on the east side, center, of the building roof. All heights are from ground level.

Table 4A. Stacks, vents, or points of radioactive materials release to the atmosphere at IRC.

\begin{tabular}{|c|c|c|c|c|}
\hline Bldg & Vent & Source Description & Effluent Control Description & Efficiency \\
\hline 603 & HRF-3 & Laboratory A-20 & NA & NA \\
\hline 603 & HRF-4 & Laboratory A13 & NA & NA \\
\hline 603 & HRF-5 & Laboratory B-15 & NA & NA \\
\hline 603 & HRF-6 & Laboratory C-4 & NA & NA \\
\hline 603 & EF-104 & Laboratory C-19 & HEPA Filter bank & $\begin{array}{l}99.97 \% \text { at } \\
3.0 \mu \mathrm{m}\end{array}$ \\
\hline 603 & $\begin{array}{l}\text { EF-102 } \\
\& 103\end{array}$ & Laboratory 104 & NA & NA \\
\hline 611 & HV-EF-4 & Laboratory 104 & NA & NA \\
\hline 611 & $\begin{array}{l}\mathrm{HV}-\mathrm{EF}-6 \\
\& \mathrm{HClO}_{4} \\
\text { fume } \\
\text { hood } \\
\text { Fan/Stack }\end{array}$ & Laboratory 105 & NA & NA \\
\hline 638 & $\begin{array}{l}\text { AHU-17, } \\
\text { AHU-18 }\end{array}$ & Room 115 & NA & NA \\
\hline
\end{tabular}


Table 5A. Stacks, vents, or points of radioactive materials release to the atmosphere at RESL.

\begin{tabular}{|c|c|c|c|c|}
\hline Bldg & Vent & Source Description & $\begin{array}{l}\text { Effluent Control } \\
\text { Description }\end{array}$ & Efficiency \\
\hline 683 & F-9 & $\begin{array}{l}\text { Laboratory } 129 \text { fume hood } \\
\text { exhaust }\end{array}$ & NA & NA \\
\hline 683 & F-10 & $\begin{array}{l}\text { Laboratory } 129 \text { fume hood } \\
\text { exhaust }\end{array}$ & NA & NA \\
\hline 683 & F-11 & $\begin{array}{l}\text { Laboratory } 130 \text { fume hood } \\
\text { exhaust }\end{array}$ & NA & NA \\
\hline 683 & F-12 & $\begin{array}{l}\text { Laboratory } 130 \text { fume hood } \\
\text { exhaust }\end{array}$ & NA & NA \\
\hline 683 & F-13 & $\begin{array}{l}\text { Laboratory } 131 \text { fume hood } \\
\text { exhaust }\end{array}$ & NA & NA \\
\hline 683 & F-14 & $\begin{array}{l}\text { Laboratory } 131 \text { fume hood } \\
\text { exhaust }\end{array}$ & NA & NA \\
\hline 683 & F-15 & $\begin{array}{l}\text { Laboratory } 132 \text { fume hood } \\
\text { exhaust }\end{array}$ & NA & NA \\
\hline 683 & F-16 & $\begin{array}{l}\text { Laboratory } 132 \text { fume hood } \\
\text { exhaust }\end{array}$ & NA & NA \\
\hline 683 & F-17 & $\begin{array}{l}\text { Laboratory } 133 \text { fume hood } \\
\text { exhaust }\end{array}$ & NA & NA \\
\hline 683 & F-18 & $\begin{array}{l}\text { Laboratory } 133 \text { fume hood } \\
\text { exhaust }\end{array}$ & NA & NA \\
\hline 683 & F-19 & $\begin{array}{l}\text { Laboratory } 134 \text { fume hood } \\
\text { exhaust }\end{array}$ & NA & NA \\
\hline 683 & F-20 & $\begin{array}{l}\text { Laboratory } 134 \text { fume hood } \\
\text { exhaust }\end{array}$ & NA & NA \\
\hline 683 & F-21 & $\begin{array}{l}\text { Laboratory } 135 \text { fume hood } \\
\text { exhaust }\end{array}$ & NA & NA \\
\hline 683 & F-22 & $\begin{array}{l}\text { Laboratory } 135 \text { fume hood } \\
\text { exhaust }\end{array}$ & NA & NA \\
\hline 683 & F-23 & $\begin{array}{l}\text { Laboratory } 136 \text { fume hood } \\
\text { exhaust }\end{array}$ & NA & NA \\
\hline 683 & F-24 & $\begin{array}{l}\text { Laboratory } 136 \text { fume hood } \\
\text { exhaust }\end{array}$ & NA & NA \\
\hline 683 & $\mathrm{~F}-1$ & Building exhaust & NA & NA \\
\hline
\end{tabular}

\section{CFR 61.94(b)(5)}

"A description of the effluent controls that are used on each stack, vent, or other release point and an estimate of the efficiency of each control device."

No effluent control equipment is associated with any of the RESL release points. There is one release point at IRC with effluent control. 


\section{CFR 61.94(b)(6)}

"Distances from the points of release to the nearest residence, school, business or office and the nearest farms producing vegetables, milk, and meat."

The nearest residence is approximately $0.4 \mathrm{~km}(0.25 \mathrm{mi}$.) to the northeast. The nearest school is approximately $0.4 \mathrm{~km}(0.25 \mathrm{mi}$.) to the south. The nearest business or office is approximately $0.1 \mathrm{~km}$ $(0.0620 \mathrm{mi}$.) east, north and south of the IRC. The nearest farm producing vegetables, milk and meat is $0.35 \mathrm{~km}(0.22 \mathrm{mi}$. $)$ to the north of the IRC.

\section{CFR 61.94(b)(7)}

"The values used for all other user supplied input parameters for the computer models (e.g., meteorological data) and the source of these data."

The meteorological input file used to calculate the MEI was IDAL11.WND from the NOAA station at Fanning Field in Idaho Falls, ID. The measurement height is 15 meters.

The CAP88-PC Version 3 modeling was performed for facilities in Idaho Falls using emission rates for 170 radionuclides. For IRC facility and RESL, releases were calculated from a single ground-level point source for receptors $100 \mathrm{~m}$ from the source in each of the 16, 22.5 degree sectors.

\section{CFR 61.94(b)(8)}

"A brief description of all construction and modifications that were completed in the calendar year for which the report is prepared, but for which the requirement to apply for approval to construct or modify was waived under $\$ 61.96$ and associated documentation developed by DOE to support the waiver."

None. 
Appendix B

Naval Reactors Facility National Emission Standards for Hazardous Air Pollutants-Radionuclides Annual Report for 2012 
Naval Reactors Facility

Calendar Year 2012

\section{Calendar Year 2012}

Naval Reactors Facility

National Emission Standards for Hazardous Air Pollutants

Report on Radionuclide Air Emissions

Prepared for the U.S. Department of Energy by

Bechtel Marine Propulsion Corporation

Bettis Atomic Power Laboratory

Under Contract No. DE-NR0000031 


\section{Calendar Year 2012 \\ Naval Reactors Facility \\ National Emission Standards for Hazardous Air Pollutants \\ Report on Radionuclide Air Emissions \\ (As Required under Subpart H of 40 CFR Part 61)}

Site Name: Idaho National Laboratory (INL)

Area: Naval Reactors Facility (NRF)

\section{Area Information for NRF}

Operator: Bechtel Marine Propulsion Corporation

Address: $\quad$ P. O. Box 2068

Idaho Falls, Idaho 83403-2068

Contact: $\quad$ M. A. DiBattista, Manager, Naval Reactors Facility

Phone: (208) 533-5526

Owner: Naval Reactors Idaho Branch Office

Address: $\quad$ P. O. Box 2469

Idaho Falls, Idaho 83403-2469

Contact: $\quad$ C. B. Haynes, Manager, Naval Reactors Idaho Branch Office

Phone: (208) 533-5317 


\section{FACILITY INFORMATION}

\section{Site Description}

The Naval Reactors Facility (NRF) is located in the west-central part of the Idaho National Laboratory (INL) site (see Figure 1). NRF is located approximately 6.7 miles (10.8 kilometers) from the nearest INL border. The nearest residence is 8.5 miles (13.7 kilometers) north-northwest of NRF. The nearest population center is Howe which is located approximately 10.1 miles (16.2 kilometers) northnorthwest of NRF. Section III provides specific information concerning the distances to locations used for dose modeling.

The climate of the INL is characterized as semi-arid. The INL is located on the Snake River Plain with an elevation of approximately 5000 feet (1500 meters). Air masses entering the Snake River Plain from the west lose most of their moisture to precipitation prior to reaching the INL; therefore, annual precipitation at the INL is light. Winds are channeled over the Snake River Plain by bordering mountain ranges so that wind from the southwest predominates over the INL. The meteorological data for the area is used in the dose modeling, as described in Section III.

Established in 1949, NRF is operated for the U. S. Naval Nuclear Propulsion Program by Bechtel Marine Propulsion Corporation, Bettis Atomic Power Laboratory. The operations area of NRF within the security fence consists of buildings, streets, and equipment covering about 84 acres. The principal facilities at NRF are three former naval reactor prototypes (S1W, A1W, and S5G) and the Expended Core Facility (ECF). The S1W, A1 W, and S5G prototypes were shut down in October 1989, January 1994, and May 1995, respectively.

Developmental nuclear fuel material samples, naval spent fuel, and irradiated reactor plant components/materials are examined at ECF. The knowledge gained from these examinations is used to improve current designs and to monitor the performance of existing reactors. The naval spent fuel examined at ECF is critical to the design of longer-lived cores, which results in the creation of less spent fuel requiring disposition. NRF also prepares and packages spent naval fuel for dry storage and eventual transport to a permanent repository. 


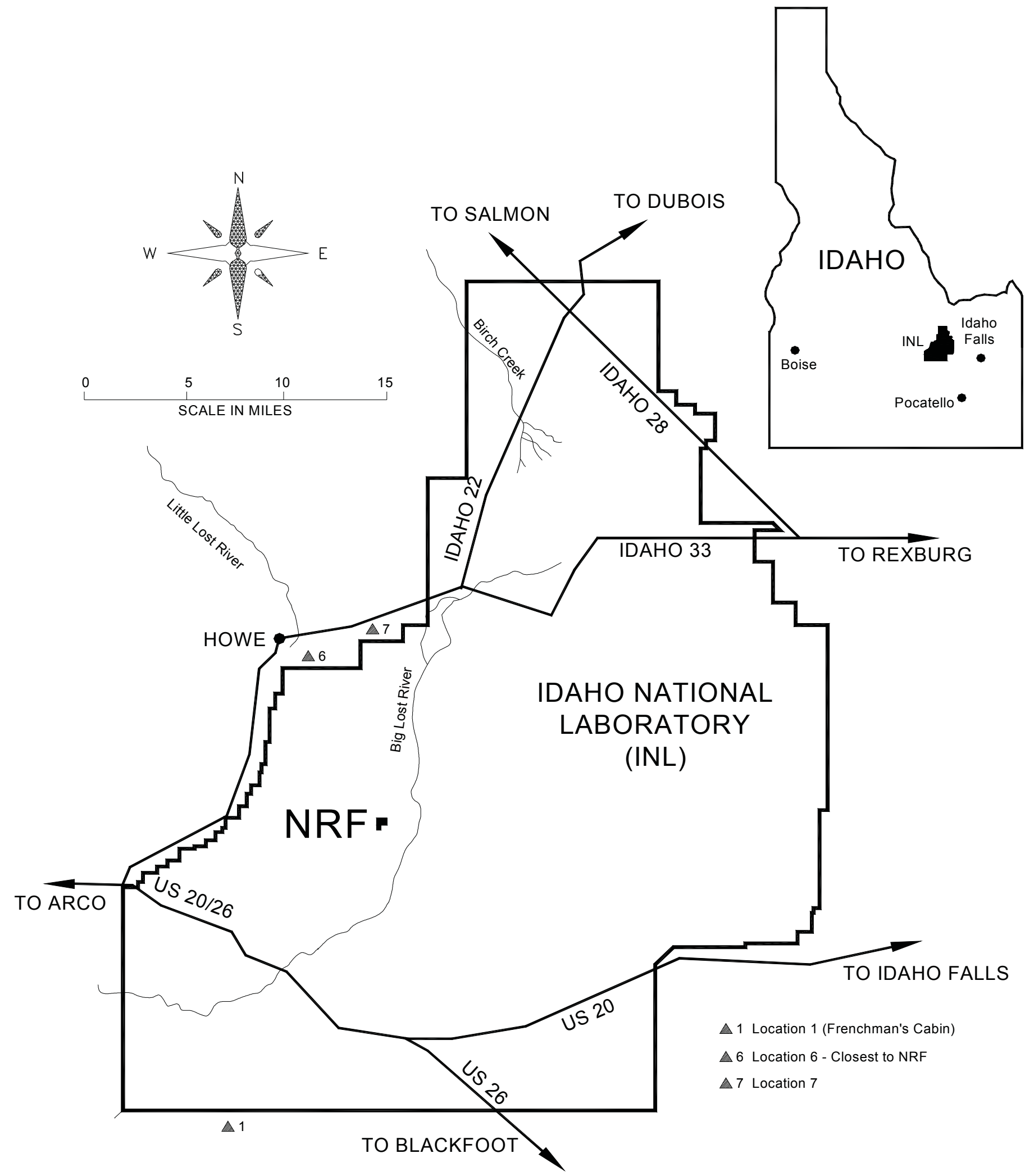

Figure 1. Relation of NRF to the INL and the Surrounding Area. 


\section{Source Descriptions}

NRF receives spent fuel and radioactive components from the U. S. Naval Nuclear Propulsion Program, shipped in Department of Energy (DOE)/Nuclear Regulatory Commission approved shipping containers in accordance with Department of Transportation requirements. The shipments are processed and examined at ECF.

Radioactive materials at NRF include enriched uranium fuel with associated fission products, activation products, and activated corrosion and wear products. Various radiation sources are used for calibrating and checking equipment, verifying shielding, and performing radiography. Soil with low levels of radioactivity from past releases is also present at NRF.

Radioactive materials are handled and processed in several areas at NRF, including shielded hot cells, chemical and metallurgical laboratories, water pools, and radioactive material storage areas. Physical, chemical, and metallurgical testing of small quantities of highly radioactive material specimens is performed in the ECF shielded hot cells. Radioactive work conducted within the ECF highbay water pools consists of unloading spent naval fuel and radioactive specimens from shipping containers, fuel examinations, removal of non-fuel structural pieces, and storage of fuel. In another part of ECF called the Spent Fuel Packaging Facility, the spent naval fuel is removed from the water pools and packaged for long term dry storage. Segregation and repackaging of radioactive waste are performed within the S5G highbay, and decontamination of inactive radiological systems proceeds throughout NRF controlled areas. Radioactive work is performed in appropriate containment. Storage and movement of radioactive materials are under strict control. Special laboratory facilities are available for the chemical analysis of low-level radioactive samples.

All radioactive material is controlled by a radioactive material accountability system and maintained in designated storage areas. All movements of radioactive material within the facility are performed under escort of qualified radiological controls personnel and tracked in the accountability system.

Radioactive liquids are used to support operations. Radioactive liquids may be processed through a series of filters and demineralizers for reuse.

Disposable materials and waste products associated with the handling of radioactive materials are controlled and tracked as radioactive waste. The waste is temporarily stored on site in designated storage areas until sufficient quantities accumulate to comprise a shipment to a DOE low-level disposal site. 
Radionuclide emissions to the atmosphere can come from three main sources at NRF:

(1) ECF, where spent fuel from naval cores and contaminated materials such as anti-contamination clothing, tools, and other equipment are handled. Radioactive water is present in the water pools where the fuel is located. Spent fuel is unloaded from shipping containers and is packaged for long term storage at a permanent repository.

(2) S1W, A1W, and S5G Prototype Reactors. Although the reactors have been shut down and defueled, routine inspections of the reactor compartments are conducted and the air exhausted from these facilities is monitored. At the S5G prototype, contaminated materials such as tools, equipment, anti-contamination clothing, and contaminated waste are handled. Analyses are performed on radioactive materials in chemistry laboratories in the A1W prototype building.

(3) Fugitive Soil Emissions, from areas surrounding NRF which potentially contain low levels of radioactivity in the soil that are exposed to the wind.

\section{AIR EMISSIONS DATA}

NRF has a number of stacks and vents with the potential to emit low quantities of radionuclides. These emissions are quantified by monitoring and/or by calculations based on production.

Continuous monitoring is required by 61.93(b) of $40 \mathrm{CFR} 61$, Subpart $\mathrm{H}$, for emission points that have a potential to emit radionuclides in quantities that could result in an Effective Dose Equivalent (EDE) to a member of the public in excess of 1 percent of the 10 millirem $\left(1 \times 10^{-4}\right.$ sievert $)$ per year standard, which is 0.1 millirem $\left(1 \times 10^{-6}\right.$ sievert $)$ per year. None of the emission points at NRF qualify for the continuous monitoring requirement; all emission points are below the 0.1 millirem $\left(1 \times 10^{-6}\right.$ sievert $)$ per year criteria. For emission points whose potential to emit is below this criteria, periodic confirmatory measurements are required to verify the low emissions.

Table II-1 identifies potential point sources of radionuclide air emissions. The table contains identification codes for area, building, and vent; a general description; a description of the effluent controls and their efficiencies; indicates whether each emission point was monitored; and presents the distance to the nearest residence, school, business, office, or farm.

Table II-2 identifies potential fugitive sources of radionuclide air emissions. The only fugitive source is windblown soil from areas on NRF property outside of the operations area, which contain low levels of radioactivity from past releases. Fugitive sources have no effluent control or monitoring. The table presents the distance to the nearest residence, school, business, office, or farm.

Tables II-3 and II-4 list the amount of each radionuclide emitted from point sources and fugitive sources. The tables include measured values for those radionuclides that are routinely monitored and calculated values for those radionuclides that are not monitored. For determining the EDE, the gross alpha radioactivity is conservatively modeled as plutonium-239 and the gross beta radioactivity is conservatively modeled as strontium- 90 . 
Table II-1. Potential Radiological Air Emission Point Sources at NRF During 2012

\begin{tabular}{|c|c|c|c|c|}
\hline \multicolumn{5}{|c|}{ Nearest Residence, School, Business, Office, or Farm: 13.7 kilometers NNW } \\
\hline $\begin{array}{l}\text { AREA } \\
\text {-BLDG } \\
\text {-VENT No. }\end{array}$ & SOURCE DESCRIPTION & $\begin{array}{c}\text { EFFLUENT } \\
\text { CONTROL } \\
\text { DESCRIPTION }\end{array}$ & $\begin{array}{l}\text { EFFICI- } \\
\text { ENCY }^{1}\end{array}$ & $\begin{array}{l}\text { MONI- }^{2} \\
\text { TORED }^{2}\end{array}$ \\
\hline NRF-601-023 & S1W Reactor Compartment & None $^{3}$ & NA & No \\
\hline NRF-601-HBRV & S1W High Bay Ventilation & None $^{3}$ & NA & Yes \\
\hline NRF-616-012, 021 & $\begin{array}{l}\text { A1W Operations Building and Site } \\
\text { Chemistry }\end{array}$ & None $^{3}$ & NA & Yes \\
\hline NRF-616-PCMA & $\begin{array}{l}\text { A1W Primary Components Maintenance } \\
\text { Area and Extension }\end{array}$ & None $^{3}$ & NA & No \\
\hline NRF-617-013 & A1W Reactor Compartment 3A & HEPA Filter & $99.95 \%$ & Yes \\
\hline NRF-617-020 & A1W Reactor Compartment 3B & HEPA Filter & $99.95 \%$ & Yes \\
\hline NRF-618-099 & ECF Stack Number 1 & $\begin{array}{l}\text { HEPA Filter } \\
\text { Carbon Filter }\end{array}$ & $\begin{array}{c}99.95 \% \\
90-99.9 \%\end{array}$ & Yes+ \\
\hline NRF-618-103 & ECF Stack Number 2 & HEPA Filter & $99.95 \%$ & Yes+ \\
\hline NRF-618-237 & ECF Stack Number 3 & HEPA Filter & $99.95 \%$ & Yes + \\
\hline NRF-618-HBRV & ECF High Bay Roof Vents & None $^{3}$ & NA & Yes \\
\hline NRF-633A-057 & $\begin{array}{l}\text { S5G Radioactive Area Ventilation } \\
\text { (RAV) System }\end{array}$ & HEPA Filter & $99.95 \%$ & Yes \\
\hline NRF-633A-HBRV & S5G High Bay Roof Vents & None $^{3}$ & NA & Yes \\
\hline NRF-733-T & $\begin{array}{l}\text { A1W Radioactive Waste Processing } \\
\text { System Temporary Ventilation }{ }^{4}\end{array}$ & HEPA Filter & $99.95 \%$ & Yes \\
\hline
\end{tabular}

1. HEPA filters are tested by the manufacturer prior to delivery to NRF and by NRF during the life of the filter. The manufacturer tests the efficiency for 0.3 -micron monodispersed dioctylphthalate (DOP) particles to a minimum of 99.97 percent. NRF tests the efficiency for 0.7 -micron polydispersed DOP particles to a minimum of 99.95 percent. The carbon filters have an efficiency of 99.9 percent for the removal of radioactive iodine when new. Their efficiency lessens with use, as the carbon adsorbent depletes. The carbon filters are replaced when efficiency drops to 90 percent.

2. "No" indicates that the source was not monitored during 2012 because it did not operate during 2012. "Yes" indicates that the source was monitored, and the measured emissions are included in this report. "Yes + " indicates that the source was monitored, and both measured and calculated emissions are included in this report. (Because some gaseous radionuclides could not be measured, the amounts of these radionuclides were calculated based on the amount of process production.)

3. Subsystems that exhaust within the areas ventilated by these sources may have HEPA filters.

4. This temporary exhaust system was set up to provide ventilation during remediation of old radiological structures and equipment. The exhaust system will be removed after remediation work is complete. 
Table II-2. Potential Radiological Air Emission Fugitive Sources at NRF During 2012

\begin{tabular}{|lcccc|}
\hline \multicolumn{4}{|c|}{ Nearest Residence, School, Business, Office, or Farm: 13.7 kilometers NNW } \\
\hline AREA & & EFFLUENT & EFFI- & MONI- \\
-BLDG & SOURCE DESCRIPTION & CONTROL & CIENCY & TORED \\
-VENT No. & & DESCRIPTION & & \\
\hline \hline NA & Fugitive Soil & None & NA & No \\
\hline
\end{tabular}

Table II-3. Point Source Releases From NRF During 2012

\begin{tabular}{|lccc|}
\hline Radionuclide & Symbol & $\begin{array}{c}\text { Release } \\
\text { (curies) }\end{array}$ & $\begin{array}{c}\text { Release } \\
\text { (becquerels)* }\end{array}$ \\
\hline Gross alpha (modeled as plutonium-239) & $\mathrm{Pu}-239$ & $2.8 \mathrm{E}-06$ & $1.0 \mathrm{E}+05$ \\
\hline Gross beta (modeled as strontium-90) & $\mathrm{Sr}-90$ & $5.6 \mathrm{E}-05$ & $2.1 \mathrm{E}+06$ \\
\hline Carbon-14 & $\mathrm{C}-14$ & $9.3 \mathrm{E}-01$ & $3.4 \mathrm{E}+10$ \\
\hline Cobalt-60 & $\mathrm{Co}-60$ & $6.7 \mathrm{E}-08$ & $2.5 \mathrm{E}+03$ \\
\hline Tritium & $\mathrm{H}-3$ & $1.9 \mathrm{E}-02$ & $7.0 \mathrm{E}+08$ \\
\hline Iodine-129 & $\mathrm{I}-129$ & $5.3 \mathrm{E}-05$ & $2.0 \mathrm{E}+06$ \\
\hline Iodine-131 & $\mathrm{I}-131$ & $4.4 \mathrm{E}-06$ & $1.6 \mathrm{E}+05$ \\
\hline Krypton-85 & $\mathrm{Kr}-85$ & $3.9 \mathrm{E}-02$ & $1.4 \mathrm{E}+09$ \\
\hline \hline Total & & $9.9 \mathrm{E}-01$ & $3.7 \mathrm{E}+10$ \\
\hline
\end{tabular}

* One curie equals $3.7 \mathrm{E}+10$ becquerels.

Table II-4. Fugitive Source Releases From NRF During 2012

\begin{tabular}{|lccc|}
\hline Radionuclide & Symbol & $\begin{array}{l}\text { Release } \\
\text { (curies) }\end{array}$ & $\begin{array}{c}\text { Release } \\
\text { (becquerels)* }\end{array}$ \\
\hline Cobalt-60 & Co-60 & $6.8 \mathrm{E}-08$ & $2.5 \mathrm{E}+03$ \\
\hline Cesium-137 & Cs-137 & $7.1 \mathrm{E}-05$ & $2.6 \mathrm{E}+06$ \\
\hline Total & & $7.1 \mathrm{E}-05$ & $2.6 \mathrm{E}+06$ \\
\hline
\end{tabular}

* One curie equals $3.7 \mathrm{E}+10$ becquerels. 


\section{DOSE ASSESSMENTS \\ Summary}

Table III-1 summarizes the EDE results for point sources, fugitive sources, and both combined. The total EDE from all NRF sources was determined to be $2.7 \times 10^{-4}$ millirem $\left(2.7 \times 10^{-9}\right.$ sievert $)$ and occurred at a location 8.5 miles (13.7 kilometers) north-northwest of NRF. The NRF EDE is for information only; it is the EDE from all INL sources combined that is used to show compliance with the 40 CFR 61.92 standard.

Table III-1. Effective Dose Equivalents from Sources at NRF During 2012

\begin{tabular}{|ccc|}
\hline Release Type & $\begin{array}{c}\mathrm{EDE}^{1} \\
(\mathrm{mrem})\end{array}$ & $\begin{array}{c}\mathrm{EDE}^{1} \\
(\mathrm{~Sv})^{2}\end{array}$ \\
\hline \hline 1. Point Sources & $2.6 \mathrm{E}-04$ & $2.6 \mathrm{E}-09$ \\
\hline 2. Fugitive Sources & $2.2 \mathrm{E}-06$ & $2.2 \mathrm{E}-11$ \\
\hline \hline Total: & $2.7 \mathrm{E}-04$ & $2.7 \mathrm{E}-09$ \\
\hline
\end{tabular}

1. The EDE shown is for the NRF maximally exposed individual (Figure 1, Location 6).

2. One millirem equals $1.0 \mathrm{E}-05$ sievert $(\mathrm{Sv})$.

\section{Description of Dose Model and Summary of Input Parameters}

\section{General}

The CAP88 computer code (CAP88-PC Version 3.0) was used to calculate the EDE from the NRF releases. CAP88 is approved for use by the Environmental Protection Agency (EPA) for demonstrating compliance with 40 CFR 61 Subpart H, "National Emission Standards for Emissions of Radionuclides Other Than Radon From Department of Energy Facilities." The output from CAP88 is the EDE, which includes the 50-year committed EDE (CEDE) from internal exposure through the ingestion and inhalation pathways and the external EDE from ground deposition and air immersion.

Site-specific 2012 wind data was used, supplied by the National Oceanic and Atmospheric Administration (NOAA). Emissions from all NRF sources were modeled as ground-level releases with no plume rise, as the most conservative approach. All sources were modeled as originating from the center of the facility. Other user-supplied input parameters are as follows:

Wind Data File: NRFL12.STR per NOAA

Annual Average Temperature: $8 \mathrm{deg} \mathrm{C}$ average in 2012 per NOAA

Annual Rainfall: $15 \mathrm{~cm}$ in 2012 per NOAA.

Humidity: $4 \mathrm{~g} / \mathrm{m}^{3}$ long term INL average calculated from NOAA data

Lid Height: $800 \mathrm{~m}$ per NOAA

Agricultural Class: Rural

The dose from daughter progeny is included by the CAP88 program. 


\section{Compliance Assessment}

\section{Maximally Exposed Individual}

Subpart $\mathrm{H}$ of 40 CFR 61 requires that emissions of radionuclides to the ambient air from DOE facilities shall not exceed those amounts which would cause any member of the public to receive an EDE of 10 millirem $\left(1 \times 10^{-4}\right.$ sievert $)$ per year. "Member of the public" is any offsite point where there is a residence, school, business, or office.

Two locations near the INL boundary were evaluated to determine which received the highest dose from NRF emissions. The first is the nearest "residence, school, business, or office" to NRF. It is a residence 8.5 miles (13.7 kilometers) to the north-northwest (Figure 1, Location 6). The second location is another residence located 9.8 miles (15.8 kilometers) north of NRF (Figure 1, Location 7). Although Location 7 is a greater distance from NRF, wind direction in some years can cause it to receive a higher dose from NRF emissions than Location 6 . The dose at both of these locations was evaluated using the CAP88 program, and Location 6 was found to have the higher dose from 2012 emissions.

The EDE at Location 6 from NRF emissions is given for information only. For compliance purposes, the EDE from all INL emissions combined must comply with the 40 CFR 61.92 standard of 10 millirem per year. NRF emissions are combined with emissions from other INL facilities to determine the overall EDE for the INL. The highest dose from all INL facilities combined typically occurs at a location south of the INL referred to as Frenchman's Cabin (Figure 1, Location 1).

\section{ADDITIONAL INFORMATION}

40 CFR 61 Subpart H requires the report to include a "brief description of all construction and modifications which were completed in the calendar year for which the report is prepared, but for which the requirement to apply for approval to construct or modify was waived".

During 2012 NRF began removal of the A1W Radioactive Waste Processing System (RWPS). The RWPS was a support system for the A1W reactor plant prototype at NRF, used to process radioactive water. The RWPS consists of several buildings, structures, tanks, and other miscellaneous equipment and piping located on a quarter-acre compound near the reactor plant building. Many of the components have internal radioactivity which presents a potential for radiological air emissions from the project. The removal will take several years to complete. The potential EDE to the public from this project was determined to be $6.12 \mathrm{E}-05 \mathrm{mrem} / \mathrm{yr}$. 


\section{SUPPLEMENTAL INFORMATION}

The following information is provided at the request of DOE Headquarters and is not required as part of the annual National Emission Standards for Hazardous Air Pollutants reporting requirements (under 40 CFR Section 61.94).

REQUEST: Provide an estimate of the collective effective dose equivalent (person-rem per year) for 2012 releases.

An estimate of the collective effective dose equivalent (person-rem per year) will be provided in the Idaho National Laboratory Site Environmental Report for Calendar Year 2012.

REQUEST: Provide information on the status of compliance with Subparts Q and T of 40 CFR Part 61 if pertinent.

Subpart Q of 40 CFR Part 61, "National Emission Standards for Radon Emissions From Department of Energy Facilities," is applicable to the design and operation of storage and disposal facilities for radium-containing material that emit radon-222 into the air. Subpart Q is not applicable to the Naval Reactors Facility. Subpart T of 40 CFR Part 61, "National Emission Standards for Radon Emissions From the Disposal of Uranium Mill Tailings," is not applicable to the Naval Reactors Facility.

REQUEST: Provide information on radon-220 emissions from sources containing uranium-232 and thorium-232 where emissions potentially can exceed 0.1 millirem (1 x 10-6 sievert) per year to the public or 10 percent of the non-radon dose to the public.

The Naval Reactors Facility does not have any sources of uranium-232 or thorium-232 emissions that potentially can exceed 0.1 millirem $\left(1 \times 10^{-6}\right.$ sievert $)$ per year to the public or 10 percent of the nonradon dose to the public.

REQUEST: Provide information on non-disposal and non-storage sources of radon-222 emissions where emissions potentially can exceed 0.1 millirem $(1 \times 10-6$ sievert $)$ per year to the public or 10 percent of the non-radon dose to the public.

The Naval Reactors Facility does not have any non-disposal or non-storage sources of Radon-222 emissions that potentially can exceed 0.1 millirem $\left(1 \times 10^{-6}\right.$ sievert $)$ per year to the public or 10 percent of the non-radon dose to the public.

REQUEST: For the purpose of assessing facility compliance with the National Emission Standards for Hazardous Air Pollutants effluent monitoring requirements of Subpart $H$ under Section 61.93(b), give the number of emission points subject to the continuous monitoring requirements, the number of these emission points that do not comply with the Section 61.93(b) requirements, and if possible, the cost for upgrades. Describe site periodic confirmatory measurement plans. Indicate the status of the quality assurance program described by Appendix B, Method 114.

The Naval Reactors Facility does not have any emission points that require continuous monitoring under Section 61.93(b). Periodic confirmatory measurements were made using a combination of sampling and calculation. Particulate radionuclides were sampled on a continuous basis. Iodine-131 was sampled on a continuous basis from two stacks. Other gaseous radionuclide emissions were calculated based on production. The Appendix B Method 114 quality assurance program is not required since none of NRF's emission points require continuous monitoring. However, a quality assurance program is followed which incorporates much of the same features, such as equipment calibration, the use of blanks and known standards, and the annual review and validation of data by peer reviewers. 


\section{ServiceID, ENVIRONMENTAL CORRESPONDENCE <envaff@inl.gov>}

\section{Fwd: Idaho National Laboratory NESHAPs CY2012 Report for Radionuclides} 1 message

Mark Verdoorn <mark.verdoorn@inl.gov>

Thu, Jun 27, 2013 at 11:46 AM

To: Robert J Rivard <robert.rivard@inl.gov>, Eirik Fowler <Eirik.Fowler@inl.gov>, E Dewayne King <E.King@inl.gov>, Tim A Solle<Tim.Solle@inl.gov>, Bradley K Griffith <Bradley.Griffith@inl.gov>, Alicia Tavera <Alicia.Tavera@inl.gov>, JohnW Gill <John.Gill@inl.gov>, Christopher M Wernert <Chris.Wernert@amwtp.inl.gov>, Robert A Montgomery<Robert.Montgomery@inl.gov>, A Jeffrey Sondrup <a.sondrup@inl.gov>

Cc: ENVIRONMENTAL CORRESPONDENCE <ENVAFF@inl.gov>

Final Rad NESHAP

Mark Verdoorn

Idaho National Laboratory

Environmental Support \& Services

Phone: 208-526-8135

Forwarded message

From: Safford, Tim J <saffortj@id.doe.gov>

Date: Thu, Jun 27, 2013 at 11:37 AM

Subject: Idaho National Laboratory NESHAPs CY2012 Report for Radionuclides

To: "Zhen.Davis@epamail.epa.gov" <Zhen.Davis@epamail.epa.gov>

Cc: "Rosnick.Reid@epa.gov" <Rosnick.Reid@epa.gov>, "tiffany.floyd@deq.idaho.gov"

<tiffany.floyd@deq.idaho.gov>, "rensay.owen@deq.idaho.gov"<rensay.owen@deq.idaho.gov>,

"susan.burke@deq.idaho.gov" <susan.burke@deq.idaho.gov>, "Anderson, Carol R"

<carol.anderson@amwtp.inl.gov>, "Robert Ramsey (Robert.Ramsey@unnpp.gov)"

<Robert.Ramsey@unnpp.gov>, "Stenzel, Jo A"<jo.stenzel@inl.gov>, "Reno, Scott L"

<scott.reno@icp.doe.gov>, "Wilhelmsen, Roger N" <roger.wilhelmsen@icp.doe.gov>, "Verdoorn, Mark A" <mark.verdoorn@inl.gov>, "Hernandez, Nicole K" <hernannk@id.doe.gov>

Davis,

Attached is the "National Emission Standards for Hazardous Air Pollutants - Calendar Year 2012 INL Report for Radionuclides." Also, attached is the report transmittal letter and the DOE certification.

Please contact me if there are any questions concerning this report

Sincerely, 
Tim Safford

Department of Energy - Idaho Operations

Environment \& Sustainability Division

1955 Fremont Avenue

Idaho Falls, ID 83401-1216

(208) $526-5670$

saffortj@id.doe.gov

\section{2 attachments}

Idaho National Laboratory NESHAP 2012 Annual Report for Radionuclides Transmittal 园 Letter and Certification.pdf $68 \mathrm{~K}$

National Emission Standards for Hazardous Air Pollutants - Calendar Year 2012 INL Report 园 for Radionuclides.pdf $568 \mathrm{~K}$ 